UNITED STATES DEPARTMENT OF- THE INTERIOR

Harold L. Ickes, Secretary

GEOLOGICAL SURVEY

W. C. Mendenhall, Director

\title{
Bulletin 926-B
}

\section{GEOLOGY OF THE \\ GERSTLE RIVER DISTRICT, ALASKA}

\author{
WITH A REPORT ON THE \\ BLACK RAPIDS GLACIER
}

BY

FRED H. MOFFIT

Mineral Resources of Alaska, 1939

(Pages 107-160)

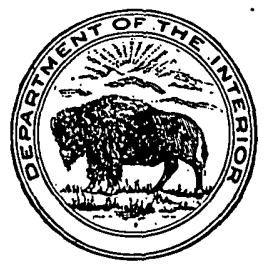

UNITED STATES

GOVERNMENT PRINTING OFFICE

WASHINGTON : 1942 



\section{CONTENTS}

Geology of the Gerstle River district, Alaska

Abstract._... 107

Introduction 108

Geography

Relief and drainage.... 109

Timber and vegetation. 113

Routes and trails............. 114

Game... 117

Geology

Outline

Undifferentiated Paleozoic or pre-Paleozoic schist and gneiss... $\quad 119$

Character and distribution

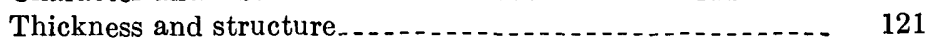

Age and correlation

Pre-Tertiary igneous rocks........... 123

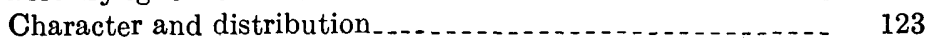

Age of the intrusives.... 126

Tertiary coal-bearing rocks...........

Character and distribution_._.

Thickness and structure

Age and correlation

Unconsolidated deposits.....

Nenana gravel.

Character and distribution

Structure

Age............ 133

Morainal deposits. . .

Stream deposits .....

Geologic history

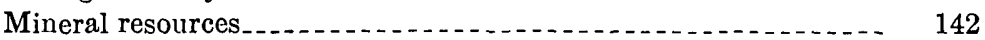

Gold.

Coal_...

Black Rapids Glacier, Alaska_.

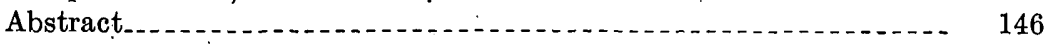

Introduction.

Physical features of the area.

Exploration and mapping in the area.................... 148

Changes observed in the glacier.

Cause of the advance of the ice.....

Index 


\section{ILLUSTRATIONS}

Puate 2. Topographic reconnaissance map of the Gerstle River district, Alaska. . . . . . . .

3. Geologic reconnaissance map of the Gerstle River district_._In pocket.

4. View southeast across Jarvis Creek Glacier from mountain rop 3 miles east of Rapids Roadhouse

5. $A$, Smooth, round-topped mountains east of Johnson River near northern border of highland area; $B$, Donnelly Dome from a point 3 miles to the southwest.........

6. $A$, Bed of white quartz fragments at base of Tertiary coalbearing deposits near head of Little Gold Creek; $B$, White quartz bed that forms base of Tertiary deposits near head of Little Gold Creek

7. $A$, Beds of coal in sandstone and sandy shale on small tributary of Jarvis Creek west of Little Gold Creek; $B$, Nenana gravel on Macomber Creek a short distance below mouth of Old Channel Creek.

8. $A$, Gravel deposits on east side of Gerstle River near the canyon: $B$, Tilted gravel beds (Nenana) near margin of highland area west of Gerstle River; $C$, Morainal deposits at margin of Tanana lowlands 8 miles northwest of Gerstle River.......

9. $A$, Weathered masses of schistose granite on ridge west of Gerstle River, 21/2 miles northeast of Bradford Creek; $B$, Boulder-strewn bed of Sheep Creek...................

10. A, Black Rapids Glacier from brow of gravel terrace above Richardson Highway, about 100 yards south of Rapids Roadhouse; B, End of Black Rapids Glacier..............

11. Black Rapids Glacier from point on gravel terrace above Richardson Highway, 2.1 miles south of Rapids Roadhouse.

Figure 4. Index map of part of Alaska showing the location of the Gerstle River district.

5. Map of drainage basin of Black Rapids Glacier as surveyed by J. W. Bagley in 1910 . . .

6. Lower part of Black Rapids Glacier as surveyed by T. W. Ranta in 1937 


\title{
GEOLOGY OF THE GERSTLE RIVER DISTRICT, ALASKA
}

\author{
By Fred H. Moffit
}

\begin{abstract}
The area here described includes most of the north side of the Alaska Range between the Delta and Johnson Rivers, in one direction, and the axis of the Alaska Range and the Tanana River in the other. Besides, the Delta River, its principal streams are Jarvis Creek, the Gerstle and Little Gerstle Rivers, and, at the extreme east, the. Johnson River, all of which have glacial sources. On the south are high, rugged mountains with snowcaps and icefields that feed not only many small glaciers but also several glaciers of much greater size. On the north are the lowlands of the Tanana River. Between the high mountains and the lowlands is an elevated plateau of varying width and with a smooth, rolling surface through which the principal streams, aided by glacial ice, have cut deep valleys. The lower country, up to approximately 2,500 feet above sea level, is covered with timber.

Most of the district is occupied by schist and gneiss that are in large part altered sedimentary beds of prevailingly quartzitic character and practically lacking in limestone members. The schist and gneiss are tentatively correlated with the pre-Cambrian Birch Creek schist, but the possibility of their being partly or wholly of Paleozoic age is recognized. These metamorphic rocks are intruded by light-colored granitic rocks in the form of dikes, sills, and larger bodies of irregular shapes, some of which occupy areas of considerable size. The intrusive rocks may represent more than one period of intrusion, but whatever their age or ages may be they were exposed to weathering and were deeply eroded before the Tertiary coal-bearing beds were laid down. No sedimentary rocks that are definitely recognized as of either Paleozoic or Mesozoic age are known in the area.

Tertiary time is represented by a thick accumulation of fine gravel, sand, and sandy clay, or shale containing many seams of lignitic coal, and by beds of coarser gravel and sand tentatively correlated with the Nenana gravel. The coal-bearing beds, of Eocene or possibly later age, are tilted in places but are only slightly consolidated, although they are older and more consolidated than the Nenana gravel.

The youngest unconsolidated deposits include glacial moraines, glacial outwash gravel that occupies much of the Tanana lowland, the sand, gravel, and silt of the present streams and lakes, and extensive deposits of wind-blown sand.

The district was prospected in the early days by men in search of placer gold and other valuable metals, and although it has not been commercially productive it shows evidence of mineralization.
\end{abstract}




\section{INTRODUCTION}

The Gerstle River district, in the sense employed in this report, comprises a small mountainous area in the most northern part of the Alaska Range, but it shows no distinctive characteristics that separate it from adjacent areas on the east and west and is not to be regarded as presenting exceptional or peculiar geologic features.

The Alaska Range is a succession of magnificent snow-capped mountains and ranks as one of the outstanding topographic features of the Territory. It lies north of the Chugach Mountains of the Pacific coast and extends in a great arc from the Canadian boundary to the Alaska Peninsula, thereby including many geologic formations of widely varying character and age and involving a complicated history of geologic processes and events, many of which are still not known or understood. This paper deals principally with the small part of the range that lies north of the main divide and that extends from the Delta River to the Johnson River, both tributaries of the Tanana River; yet it also deals with some of the adjacent area. The country described is here designated the Gerstle River district, although it includes not only the Gerstle River drainage basin but also some contiguous areas. The position of this district in the Alaska Range is shown in figure 4.

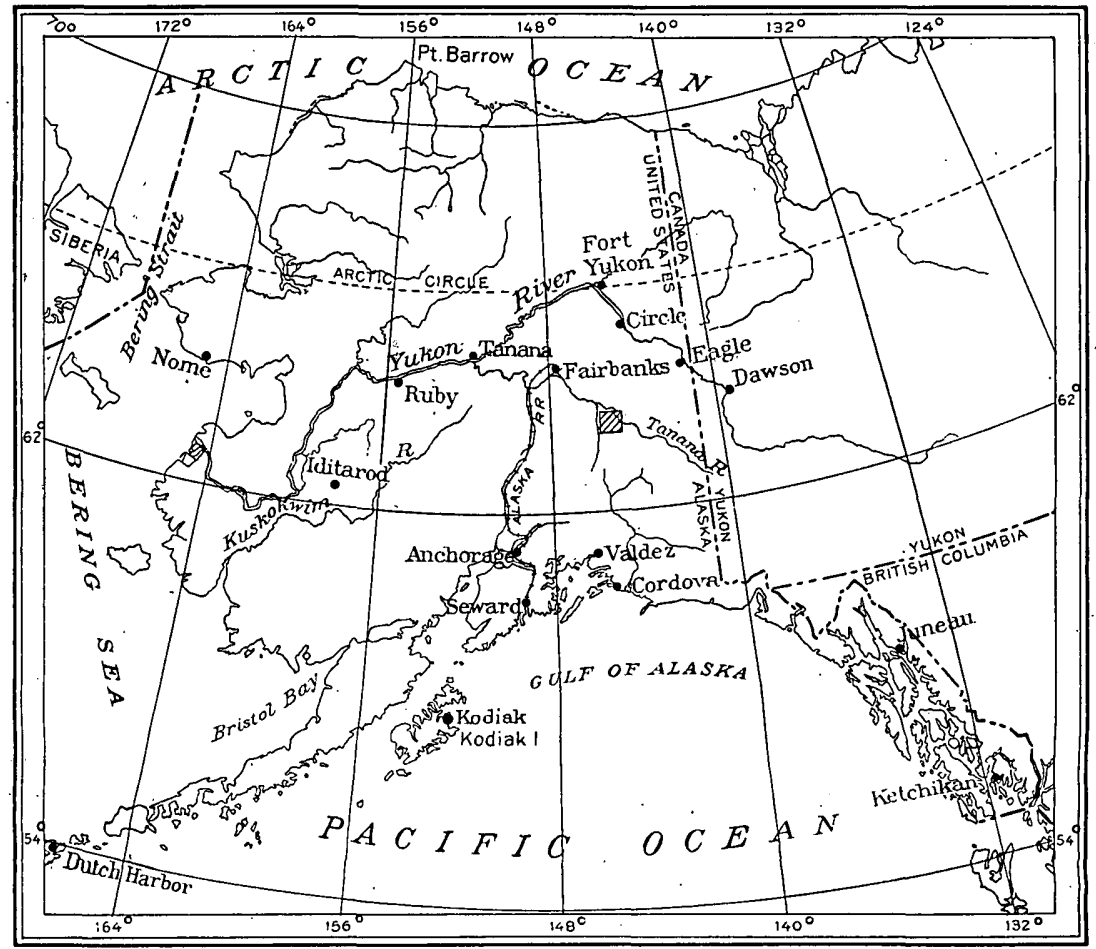

FIGURE 4.-Index map of part of Alaska showing the location of the Gerstle River district. 
The topographic map (pl. 2) that serves as the base for showing the areal geology of the Gerstle River district is compiled from several surveys. That part with which this report is especially concerned, as indicated above, was mapped by Gerald FitzGerald in 1936 and includes most of the territory on the north side of the range between the Delta and Johnson Rivers. Other parts are based on surveys by T. G. Gerdine in 1902; by J. W. Bagley, D. C. Witherspoon, and C. E. Griffin in 1910; and T. W. Ranta in 1937.

The geologic map (pl. 3) gives the results of the geologic investigation made by the writer in 1939, together with some information collected in earlier years, especially in 1910 and 1937. It is entirely reconnaissance in character. This investigation was a continuation \& of a project that has been under way for several years and has as its object the mapping of all the Alaska Range lying east of the Delta River.

The geologic survey of 1939 was made by a party consisting of three men in addition to the writer, who was in charge of the expedition. These men were Ira Morgridge and Joe Smith, packers, and Barney Dawson, cook, all of whom were experienced and gave faithful'and efficient service. The party was equipped with a pack train of 12 horses, the necessary camp gear, and food supplies sufficient for a season of about 90 days in the field. It was assembled at Gulkana, on the Richardson Highway, and left there for the old Donnelly Telegraph Station on June 20, after the pack gear had been set up and the provisions sorted for convenience in transportation. At the end of the season it returned to Gulkana and was disbanded there on September 12.

The area covered by the reconnaissance geologic survey in 1939 was somewhat less than 1,000 square miles. This area comprises mountains chiefly and does not include a wide expanse of lowlands between the mountains and the Tanana River, where none of the bedrock formations are known to crop out.

\section{GEOGRAPHY}

\section{RELIEF AND DRAINAGE}

Most of that part of the Alaska Range and adjacent area to be described in this report lies between the crest of the range and the Tanana River and extends eastward from the Delta River to the Johnson River. Within this area three topographic districts, distinct in character and location, may be distinguished. On the south are high, rugged mountains (pl. 4) that form the main mass of the range, which here trends eastward and westward and has a width of roughly 40 miles. Many of these mountains are covered with perpetual snow. They reach their greatest height in Mount Kimball 
(about 10,000 feet), near the head of the Robertson River, but are only slightly lower in the region between the Delta River and Mount Kimball.' They mark the gathering ground of snows, from which come the many glaciers that creep down their sides and feed the streams below.

These rugged mountains of the central part of the range are bordered on the north by lower mountains, which are part of a highland area characterized by smooth-topped hills and gently sloping surfaces (pl. 5, $A$ ). The highland area nowhere exceeds a dozen miles in width and is no more than half that wide in its narrower parts. It has its greatest development between the Johnson and Robertson Rivers. Its peculiar character is best seen from points on its own surface or from some higher point, for it is deeply trenched by the valleys of the glacial streams that cross it and the continuity of its surface is not easily recognized from the valley floor. In places this surface slopes slightly toward the north.

Near the borderline between the highlands and the Tanana lowlands is a landmark of interest to all travelers along the Richardson. Highway. This landmark, which is east of the road near mile 253, is the lone mountain that rises a thousand feet above the surrounding rolling country and that for many years lias borne the name of Donnelly Dome (pl. 5, B). It stands far from any comparable object and is conspicuous from whatever direction it is seen.

The highland area is succeeded on the north by the wide lowland of the Tanana Valley, which has an elevation of slightly more than 1,000 feet above sea level at the mouth of Jarvis Creek and of approximately the same elevation at the mouth of the Johnson River.

The lowland area in the Tanana River Valley is occupied in partthat is, near the places where the rivers from the Alaska Range leave their highland valleys to cross it-by low, irregularly shaped hills and ridges of morainal material, between which lie many small ponds and lakes. Much the greater part of the lowland area, however, is flat country with almost no relief and underlain by outwash gravel from the glaciers and by stream deposits. This area is covered with a scanty growth of timber, especially of young trees and vegetation that have come up on land where fire destroyed the original growth.

Mount Kimball and the high mountains west of it form a central area from which streams, radiating in all directions, contribute to the drainage of both the Tanana and Copper Rivers. Only those streams that flow directly into the Tanana River, however, together with the Delta River and some of its tributaries, are described in this report.

Beginning on the west, the principal streams are the Delta River and its tributary Jarvis Creek, and the Gerstle, Little Gerstle,.Johnson, and Robertson Rivers. All of them are glacial streams flowing in deep, 


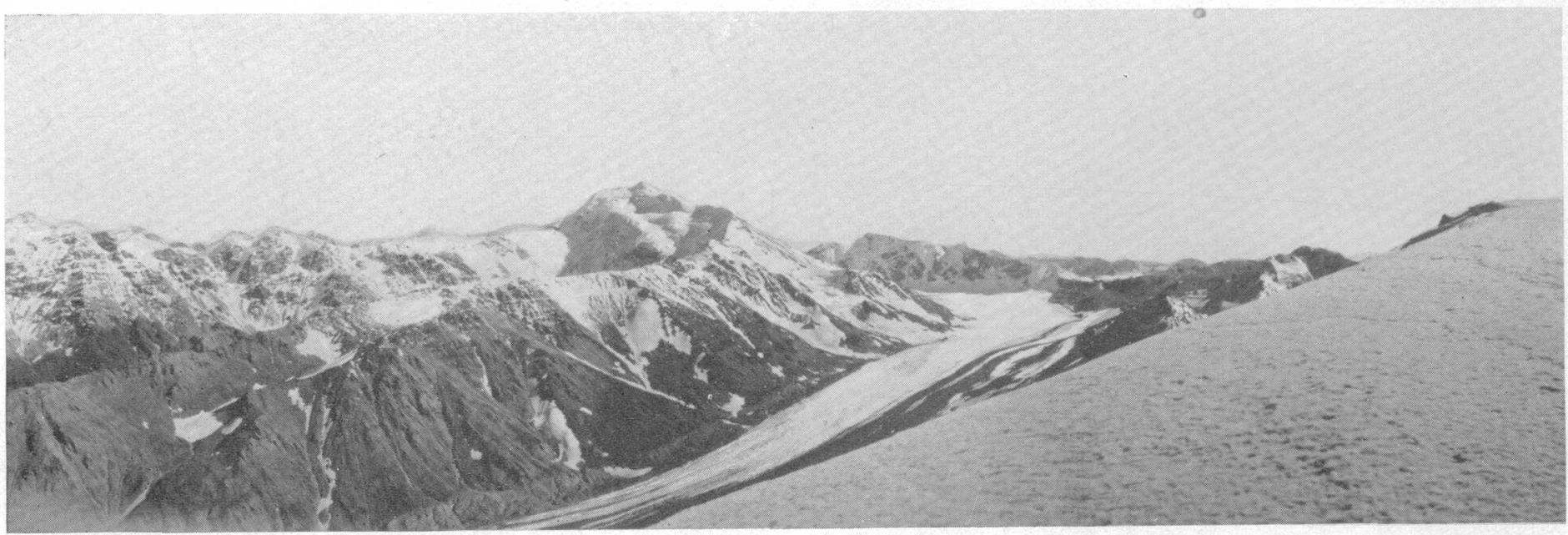

VIEW SOUTHEAST ACROSS JARVIS CREEK GLACIER FROM MOUNTAIN TOP 3 MILES EAST OF RAPIDS ROADHOUSE. Altitude about 6,500 feet. Shows the rugged form of the mountains in the higher part of the Alaska'Range. 


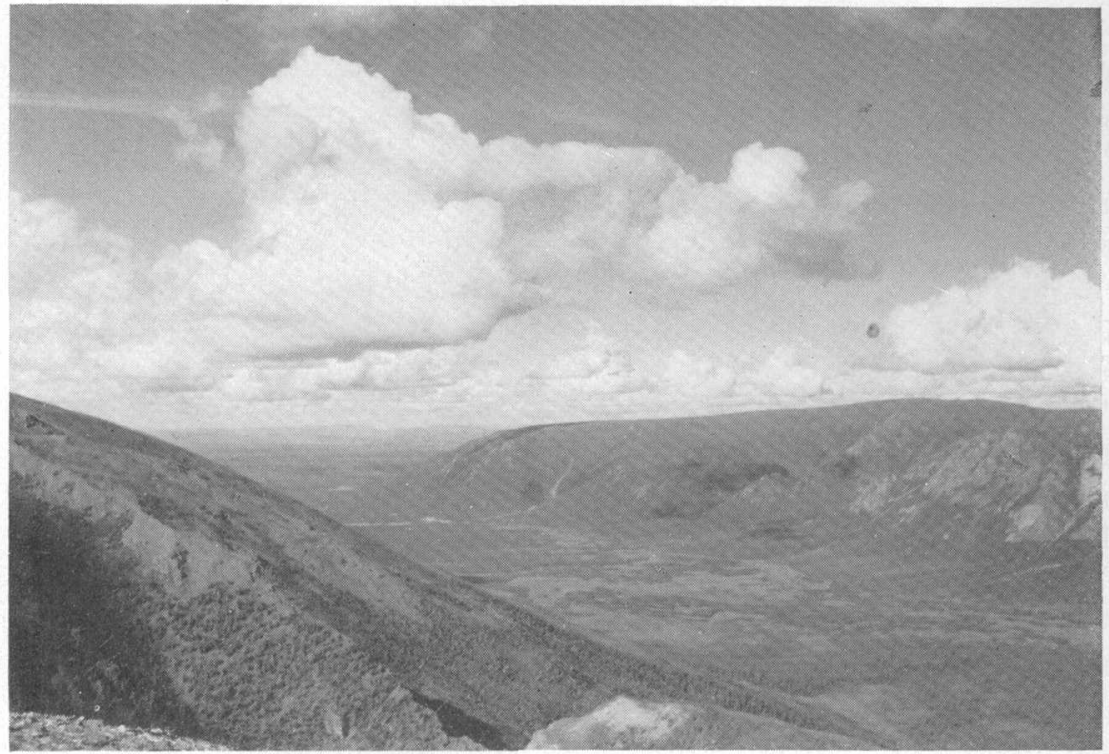

A. SMOOTH, ROUND-TOPPED MOUNTAINS EAST OF JOHNSON RIVER NEAR NORTHERN BORDER OF HIGHLAND AREA.



B. DONNELLY DOME FROM A POINT 3 MILES TO THE SOUTHWEST.

Altitude 3,600 feet. This mountain rises more than 1,000 feet above the adjacent lowland and is a con. spicuous landmark near the Richardson Highway. 
glaciated valleys that are cut directly across the mountain and highland area, but spreading out and following more devious courses through the lowlands. Heavily loaded with silt, they transport large quantities of gravel and coarser material, so that even in the mountain area their flood plains are mostly wide and their channels complicated. The general courses of all except the Delta River and Jarvis Creek are north-northeast or northeast; that is, they are nearly at right angles to the course of the Tanana River, into which they flow.

The Delta River has its source in the northern part of the Copper River lowland area, but instead of joining the Copper River it flows north in a canyonlike valley directly across the Alaska Range to the Tanana. Its valley affords one of the three principal passes leading - from the Copper and Susitna River Valleys to the Tanana Valley, and, because of its location, it became the route of the Richardson Highway, which connects the town of Fairbanks in the interior with Valdez on Prince William Sound.

Jarvis Creek, a stream about 35 miles long, rises only 5 miles east of the Delta River and flows northward to join it 10 miles from the Tanana River without at any place being as much as 10 miles distant from the Delta. Most of its valley is open; but for a few miles southsoutheast of Donnelly Dome, near the month of Macomber Creek, it flows in a box canyon strewn with boulders, which make it impassable for travel by pack train. The largest tributaries of Jarvis Creek are Riley and Macomber Creeks.

The Gerstle River has its main source in a glacier 17 miles east of the Delta River, but one of its larger tributaries, July Creek, flows from a smaller glacier between the Gerstle Glacier and Riley Creek Glacier. Leaving the glacier of its origin, the Gerstle River flows 21 miles northeast by north to a point only 3 miles from the Tanana River, then turns abruptly north-northwest, and finally joins the Tanana after holding a course nearly parallel with it for 16 miles. Its flood plain and valley floor range from 1 to 2 miles in width except in a short stretch outside the mountain area, where the river flows for several miles in a canyon cut partly in bedrock and partly in glacial deposits.

The Little Gerstle River is a much smaller stream. From its glacial source to the Tanana River at its mouth the distance is less than 9 miles. For 5.5 miles the river flows through a narrow mountain valley in a channel paved with granite boulders, but after leaving this upper valley and entering the abandoned valley of the Johnson River it follows a more open course, although in places it is confined between high gravel banks.

The Johnson River originates in one of the larger glaciers of the district and receives much additional water from several headwater tributaries that also originate in glaciers. Within the mountain area, 
the Johnson River flows directly north over a wide flood plain and at no place is confined within a narrow canyon. Outside the mountain area it turns abruptly eastward and flows to the Tanana River. Its valley, like that of all the other large stream valleys of this district, is distinctly $U$-shaped.

A striking topographic feature of this vicinity is the wide, lakedotted, glacial valley that connects the valley of the Johnson River with that of the Little Gerstle River. This valley doubtless at one time received part of the ice flowing out from the upper Johnson River Valley. The Johnson River, although only about 24 miles long, is a large, swiftly flowing stream and in times of high water offers a serious obstacle to travel; so much so that the topographic party that surveyed this area in 1936 was blocked for several days in its attempts to cross the stream.

The Robertson River is the largest stream flowing from the Mount Kimball area. It has two main branches, the western branch of which heads in the same mountain mass as that from which the eastern headwater tributaries of the Johnson River flow. This branch however takes an east-northeast course and joins the south branch, which flows from the Robertson Glacier on the east slope of Mount Kimball, 11 miles from the Tanana River. The Robertson River, like the Johnson, is a large glacial stream particularly treacherous in times of high water.

Between the Johnson and Robertson Rivers is a bare highland country with scanty timber on the lower slopes and drained by streams, most of which have small glaciers at their heads and which occupy valleys of distinctly glacial form. A few of the smaller streams in this area do not reach back to the high-mountain area and thus, having no contribution of glacial water, are clear. None of the streams of the highland area carry as much water as the other streams that have been described.

The large streams of the district possess one feature in common, which is particularly noticeable and of much importance. Their valleys, at least in summer, are often swept by strong winds, which blow northward from the high-mountain area toward the Tanana lowland and which move vast quantities of fine sand and dust that have been picked up from the dry bars and raised in dense clouds high above the streams, to be borne for miles over the lowland area. The heavier particles that are too large to be carried through the air are driven over the surface of the flood plains as slowly traveling dunes or streams of sand. This sand, mostly quartz from which the lighter-weight and darker-colored minerals have.been separated by the sorting action of either water or wind, is derived chiefly from the weathering of quartz veins in the schist and from the granite intrusives. Sand beds 
and dunes, a few inches to a few feet thick, held together and temporarily kept in place by the roots of plants, are common on the gravel bars. The finer wind-blown material is far more widely scattered, however, and forms loess deposits of variable thickness over broad areas of the lowlands. These loess deposits are most extensively developed and thickest on the terraces bordering the flood plains, the nearby source of the material. Such deposits nearly everywhere cover the gravel on the terraces.

\section{TIMBER AND VEGETATION}

The purpose of this section is to give to prospectors and travelers a few facts about the distribution of useful timber and of the plants - available for forage. It is not to discuss the quality and quantity of timber and its availability for the lumberman. The term timber as applied to the district refers chiefly to the stand of spruce trees, which grow in practically all the lowland areas and on the lower slopes of the mountains up to an indefinite altitude somewhere between 2,500 and 3,000 feet above sea level. In favored localities spruce grows above 3,000 feet but, on the other hand, fails to reach 2,500 feet where the conditions of life are unfavorable. Nearness to glacial ice. does not seem to be conducive to the best development of spruce, and as a rule the better trees are not found near the glaciers. This, however, may be partly a matter of altitude rather than the influence of the ice. The largest and finest of the trees commonly grow on the well-drained terraces of the lower valleys and the lower hill slopes. Nearly everywhere within the limits of altitude favorable to growth, trees suitable for house logs and for the usual requirements of prospectors are to be found. In places birch, poplar, and aspen are mingled with the spruce but do not equal it in suitability for most purposes. Their yellow leaves give the landscape its dominant color in autumn.

Some areas have lost their best trees. A large proportion of the land once occupied by timber was burned over in the early days and is now covered by a young growth that in many places is thick and healthy and has reached a height of 8 to 10 feet, above which occasional trees stand still higher.

The more common and abundant grasses of the district are those known to prospectors as "red top" and "bunch grass." Together with "pea vine" and willows they provide forage in most of the area except the wooded parts of the Tanana lowlands, where feed for pack animals is often hard to find. Grass commonly grows best in the upper parts of valleys and on the hill slopes near the timber line. Pea vines flourish on the flood-plain bars. They belong to the family of vetches and are of several varieties, some of which appeal to the taste of horses more than others. At some stages of their growth they are distasteful 
even to horses and are avoided by them. In addition to the different grasses and vetches, a variety of Equisetum and the leaves of certain willows should also be mentioned as forage plants, for horses eat them with relish and will subsist on them without grass if necessary.

In general, it may be said that feed for stock is plentiful in summer in most parts of the district except the lowlands north of the mountain area. Locally it is remarkably plentiful, as on the bars of Jarvis Creek and the upper Johnson River, which produce an abundance of grasses and pea vine and are a true "horse heaven" in summer. Although the winters are severe, horses have wintered for many years on the bars of some of the streams, where, like the buffalo, they are able to get sufficient food to maintain themselves from one growing season to the next. However, it is doubtful if these bars can support any considerable number of horses the year round without much hardship and hunger.

\section{ROUTES AND TRAILS}

Routes rather than trails may well be considered to be the subject of this section since the trails are few and with one or two exceptions are now used so infrequently that they are obscure and not easy to follow. In general, they cross the ridges and drainage lines of the district at right angles so that in places they are either very steep or wet; yet notwithstanding their shortcomings they are of much help to travel with horses or on foot. All lead eventually to the Richardson Highway or the Tanana River.

The Richardson Highway follows the valley of the Delta River through the Alaska Range and is the only feasible land route for approaching the country that lies on the north side of the Alaska Range between the Delta and Robertson Rivers. However, it is not the only means of access. The Tanana River is navigable for small power boats and is used for distributing supplies to the trading stations of the upper river, particularly those at Tanana Crossing and Tetling Lake. By this means supplies for the Geological Survey topographic party of 1936 and hunting parties of earlier years were delivered at the mouth of the Little Gerstle River, where they were then accessible for transport by pack train into the adjacent country on the south.

The present highway took the place of trails that had already been in use for some time. Most of the early prospectors who went into the valleys of the Delta River and Jarvis Creek came from the Fairbanks district before the Richardson Highway was established. Their trails from the 'Tanana River are not used now, as the highway provides a better mode of travel. At present little prospecting goes on in the district, and most of the traveling is done by trappers and hunting parties. The route used by the Geological Survey field parties is in the main that which has been used by hunting parties in going to 
Jarvis and Riley Creeks and the Johnson River. In parts of this route fairly well defined trails have been made; but as a rule each traveler chooses his own trail as the occasion requires.

A route that has served for travel by horses and even by tractor leaves the Richardson Highway at mile 247.8-31/2 miles north of Donnelly Station-crosses the ridge on the east to Jarvis Creek, and reaches that stream 4 miles below the mouth of Riley Creek, to which the bars of Jarvis Creek give easy access. From the mouth of Riley Creek it runs through the timber for a short distance and climbs to the open country of the ridge on the east, which country, though providing no trail, is above timber line and affords good footing for horses. After crossing the open country to the head of Macomber Creek this route leads up to a saddle overlooking the head of the Gerstle River, from which it makes a steep descent to July Creek. The approach to the saddle is gradual for most of the way but ends in a steep pitch at the top. The descent to July Creek, however, is abrupt and, as there is no trail, care is needed to keep pack animals out of danger from loose boulders and rock ledges. From July Creek the bars of the Gerstle River furnish easy going for 8 miles downstream to the old cache on its west bank. Here, at the crossing of Big Gerstle, is a well-defined trail to the top of the ridge on the southeast. Although the trail ends on the brow of this ridge, the bare hilltop furnishes good footing as far as a saddle 3 miles to the southeast, overlooking the valleys of Sheep Creek and the Little Gerstle River. The descent to the Little Gerstle River is by a trail through, the timber on a steep mountain side, where care is necessary in places to avoid soft ground. The trail was made for the use of a hunting party and leads to Hajdukovich's hunting lodge on the east side of the Little Gerstle River 1 mile above the mouth of Sheep Creek. Below or north of the hunting lodge the bars of the Little Gerstle River provide a route, indicated by a trail in a few places, to the Tanana River. South of the hunting lodge a soft, swampy trail leads along the east side of the valley to the bars of the Johnson River. Travel on the bars of the west side of the Johnson River is good as far as the glacier, although there is no trail except at one or two points where the river swings against its west bank.

In the highland country between the Johnson and Robertson Rivers there are no trails. The traveler must pick his way as best he can and may travel far to find wood and grass suitable for a camping place.

An alternate route from the Delta River that may be used in place of the one just described starts from the Richardson Highway about 3 miles south of Beales Cache, an old, abandoned roadhouse on the highway near mile 361.5. This route provides a well-defined trail 
from the highway eastward as far as Granite Creek or a little beyond, that is, for about 10 miles. The trail is over the glacial moraines and for most of the way gives hard footing and easy travel for horses, although it has a little soft ground on the west side of Jarvis Creek.

From Granite Creek this route leads along the margin of the Tanana lowland area to the cache on the Gerstle River, where it joins the route already described. Inasmuch as any trails that may have existed in this part of the route are now practically obliterated, the traveler can do no better than use his own best judgment in picking a way through timber and swamps and glacial moraine.

The obstacles to travel that are most likely to give trouble in this district are glacial streams, soft ground, and ground strewn with granite blocks or boulders that are overgrown with moss or other vegetation. Inasmuch as the Richardson Highway is on the east side of the Delta River this stream gives no concern to the traveler going east from the highway. Among the remaining streams the Johnson River is the one most likely to cause trouble, for in times of high water it cannot be crossed without some danger of losing horses and packs. In the summer of 1936 the Geological Survey topographic party forded the river at a place opposite the granite point, where the trail from the Little Gerstle River reaches the Johnson River Valley. The high water at that time made it necessary to delay crossing several days before a favorable stage of water was found. The return journey some weeks later was made without difficulty as the water was lower.

Both Jarvis Creek and the Gerstle River afford many places favorable for crossing with horses and ordinarily give little trouble. The Little Gerstle River is a much smaller stream, which for the most part is easily forded.

Quicksand is not present on most of the streams within the mountain area, but soft ground is found in the lowland area. Wet, swampy ground is such a common cause of trouble in pack-train travel throughout most of Alaska that the experienced traveler is constantly on the watch for it. Soft ground, though it may be almost anywhere, is often found along the foot of the hill slopes and along small streams in poorly drained land. Wet ground is likely to be marked by a growth of small willows.

In some parts of the Delta district horses are in more danger from concealed holes between boulders partly or wholly covered with vegetation than from swampy ground. The granite areas have yielded a great quantity of blocks and boulders that rolled down the mountain sides or were heaped together by glaciers. In places where this loose material has been overgrown by vegetation without having the spaces between the boulders filled with gravel or other fine material, a horse stepping into a hole may injure himself. 


\section{GAME}

Although game animals inhabit most parts of the Gerstle River district, so far efforts to establish the country as a hunting ground for hunting parties from the outside have been only moderately successful. Some years ago Mr. John Hujdukovich laid out trails and built cabins to accommodate hunting parties in the Johnson River Valley. For several seasons these cabins were used in the manner intended, but n more recent years they have been occupied only by local sportsmen, who were concerned chiefly with getting their winter's supply of meat. Although much of the district is too remote to be visited even by local hunters in the hunting season, most of it is covered by trap lines in winter.

The larger game animals include the moose, caribou, sheep, bear, wolf, and coyote. Sheep are found throughout the district. As is common elsewhere the bucks keep to the high mountains in summer, but the ewes and lambs graze out on the highland areas and are thus more frequently in view. Caribou, like the sheep, are widely distributed and are often seen grazing on the bare highlands or traveling on the river bars. Moose do not frequent the high mountains or the bare highland areas but feed near the many lakes of the lowlands and in the valleys, where they can quickly find cover in the timber. Though its tracks are common, the moose is a wary animal and keeps hidden most of the time when not feeding in the water. Bears also are widely distributed but, so far as observation by the Geological Survey parties would indicate, are less numerous than on the south side of the Alaska Range in the upper Copper and Nabesna River districts. Wolves and coyotes appear to be more numerous than in any other part of Alaska familiar to the writer. During the field season of 1939 the Geological Survey party members saw about 15 wolves and as many coyotes. Inasmuch as the wolf habitually keeps under cover at all times during daylight, the number seen in 1939 is regarded as remarkable. Wolves make a practice of following the bands of caribou, doubtless with the intention of picking off an animal when the opportunity comes, and will stay for days near grazing horses. Although some difference of opinion exists as to how destructive these animals are, it seems reasonable to believe that the large proportion of caribou cows without calves and of ewes without lambs that was noticeable during the season of 1939 is due to the depredations of wolves and coyotes.

Although the buffalo is protected and is not a game animal in the same sense as the other animals mentioned, it is interesting to note that the animals introduced on the bars of the Delta River and Jarvis Creek several years ago by the Biological Survey are reported to have increased from about 30 to nearly 200. From the Richardson High- 
way a person with glasses may sometimes see them on the bars of the Delta River, and he may occasionally meet them on the highway itself. An albino calf was born in the herd in 1939.

\section{GEOLOGY}

\section{OUTLINE}

The dominant rocks of the Gerstle River district are schist and gneiss of pre-Paleozoic or possibly Paleozoic age. They are metamorphic rocks, derived partly from old sedimentary beds and partly from igneous intrusives and are conspicuously lacking in calcareous members. They are found throughout the district. The schist and gneiss are intruded by granite and related granitic rocks occurring in the form of dikes, sills, and larger masses of irregular shape. Most of these igneous rocks are not much altered, if altered at all, and therefore, unlike the schist and gneiss, show little tendency to cleave along definite planes.

Subordinate in amount and much younger in age than the schist and gneiss are beds of sand, gravel, and clay, which locally contain beds of lignite. These younger beds are only partly consolidated. They lie on the eroded surface of the schist and gneiss and are restricted to a few small areas, which probably represent formations that were once more extensive than at present. They are correlated with the Tertiary coal-bearing beds that crop out in much larger bodies farther west along the north front of the Alaska Range.

Unconsolidated materials constitute the remaining geologic formations. Well-stratified and slightly tilted beds of unconsolidated coarse gravel and grit, identified with the Nenana gravel of the Kantishni district, are found in a few places. They are not distinguished with certainty from the older Tertiary gravel deposits and, on the other hand, may be confused with still younger deposits. These younger unconsolidated deposits are morainal material, sand, gravel, silt, and loess laid down by glaciers or by streams and lakes and the wind. They complete the stratigraphic column of the district.

Meager knowledge of the facts makes the geologic history of the district seem simpler than it is. An ancient group of much-altered sedimentary beds and intruded igneous rocks was invaded by granite and other closely related intrusives at some time not certainly known but probably in the late Mesozoic. Possibly more than one such invasion occurred. This assemblage of rocks gives little or no suggestion of the complicated geologic processes that must have taken place during most of the Paleozoic and Mesozoic eras. However, two of the processes that affected the district are clearly evident. First, the old rocks underwent a long period of erosion during which great accumulations of fresh-water deposits, including coal beds, were built 
up. Second, mountain-building forces became active and, assisted by the processes of erosion, gave rise to the Alaska Range-though not exactly in the same condition as we see it now, for the forms produced by the more common agents of erosion have been modified by recent glacial action not yet ended.

\section{UNDIFFERENTIATED PALEOZOIC OR PRE-PALEOZOIC SCHIST AND GNEISS}

\section{CHARACTER AND DISTRIBUTION}

Schist and gneiss are the country rocks in most of the area here considered (pl. 3 , in pocket). These terms are used to designate all the metamorphic rocks of the district, although they include a relatively small proportion of slate and much quartzite that is only subschistose in structure. In wide areas the schist and gneiss are concealed by unconsolidated fragmental deposits-silts, gravel, sand, and morainal material - and in at least one relatively small area are overlain by more or less indurated Tertiary coal-bearing beds. They are intruded by granite and other related igneous rocks of much younger age that occur as dikes and sills and as larger bodies that rank second to schist and gneiss in areal extent.

The schist and gneiss are derived partly from sedimentary beds and partly from igneous rocks, which are believed to be mainly old intrusives but may include effusives also. These two types of metamorphic rocks grade into each other in such a way that no sharp line of demarcation can be drawn between them. Consequently no attempt is made to separate them on the geologic map, either on the basis of their petrographic characteristics or on that of their origin, since to do so would require far more time and detailed study than could be given to the problem, assuming that it could be done at all.

They occur in great variety, as would be expected in view of their origin, and show a wide range in degree of metamorphism. The colors are dominantly gray in varying shades but include green and black and suggestions of pink and lavender. Some of the more siliceous varieties have a bright silvery aspect, but the darker grays are more common. The texture grades from that of fine slate with plane cleavage and constituent minerals so small as to be unidentifiable in the hand specimen to that of coarse, crinkly schist and gneiss with easily recognizable mineral components. Garnet is a common constituent of the schist and occurs in bodies of all sizes from tiny, wellcrystalized grains hardly visible with a hand lens to imperfect crystals almost an inch in diameter. Other metamorphic minerals are present. also, such as hornblende, which occurs in one locality in thin blades several inches long associated with great numbers of tiny red garnets. 
Aside from variations of color and size of mineral constituents and the presence or absence of conspicuous metamorphic minerals such as hornblende and garnet, the schist and gneiss show no unusual features; yet one common type is worthy of special mention. In many localities the rocks are characterized by an arrangement of minerals that gives them the appearance of a light gray paper ruled with thin, closely spaced lines in the manner known to draftsmen as section lining. This feature is best observed on a joint face or on a smoothly rounded boulder, and on examination it is seen to be due to the alteration of thin layers of quartz with mica, or of quartz and subordinate feldspar with mica; the alternating layers are commonly less than one-sixteenth inch thick and actually are lenticular in form, as will be seen on close examination. The resulting cleavage is plane in most instances. Occasionally, however, the layers are folded and closely compressed, and the cleavage follows the layers of mica around the folds. For many of these rocks the designation gneiss is more applicable than schist; yet when the lamellae are very thin the distinction can hardly be made. Similar rocks occur on the Robertson River, where they were described as sheared quartzite. ${ }^{1}$ In the Gerstle River district, however, some of the schist or gneiss possessing this feature is plainly derived from igneous intrusives, and it is therefore concluded that the members of this striking group are derived partly from sedimentary rocks and partly from igneous rocks.

One feature of the schist and gneiss that is universal and of much importance is the abundance of vein quartz. The largest and most conspicuous veins are bodies of milky white quartz that fill joints and other large fracture planes in the country rock; but the veins that are most important, both in number and in volume of material contained, are the small, contorted lenses and stringers that follow the cleavage planes of the schist and gneiss. Their hardness and resistance to weathering make them almost the only constituent in much of the unconsolidated material derived from the old rocks. As will be seen later, the basal members of some of the gravel deposits are made up of this vein quartz.

The field relations make it evident that the schist exposed in some places was derived from original beds of sand and grit interstratified with beds of mud, among which the siliceous or sandy members seem to have predominated. The sand now appears as sheared quartzite or silvery siliceous schist and the mud beds as gray schist. Thin beds of limestone were interstratified with the schistose members in a few localities, but, on the whole, limestone is notably absent throughout the area.

${ }^{1}$ Moffit, F. H., Geology of the Slana-Tok district, Alaska :-U. S. Geol. Survey Bull. 904, p. 13, 1938. 
Most of the rocks that are referred to as gneiss are probably metamorphosed igneous intrusives of the more acid types. They show the constituent minerals of such intrusives and in many places have such field relations as suggest their intrusive nature. They differ from the later intrusives, which are not recrystallized and do not show any marked tendency to cleave in definite directions. Such rocks occur in many localities. Exposures of the older, metamorphosed intrusives are seen on the west side of the Gerstle River Valley a few miles below Bradford Creek. The rocks there are less altered than in some other localities and occupy a larger area than was noted elsewhere. The rocks on the west side of Donnelly Dome are coarse gneiss showing quartz, micas, and feldspars plainly in the hand specimen. As Donnelly Dome was not examined in detail, the extent of such rocks was not learned; but it is suggested that differential weathering of these older intrusives may account for the presence of this striking topographic feature of the Delta River Valley. The old sedimentary beds were invaded by igneous rocks that appear to be chiefly granite or rocks of granitic character, although the intrusives probably also included types of igneous rocks more basic than granite and diorite. The intrusion by these igneous rocks took place before the sedimentary beds were changed to schist, for the intrusives are themselves metamorphosed equally with the host rocks. At some later time, howeverthat is, at some time after the schistose and gneissic structures had been induced in the older rocks-further intrusion by granitic rocks took place. The later intrusives are relatively unaltered, so that the evidence for at least two periods of intrusion of the old sedimentary beds is well established.

The more recent granitic intrusives are easily distinguished from the metamorphosed types and apparently occupy as great or greater areas. They will be described in a later section.

\section{THICKNESS AND STRUCTURE}

Thickness and structure are facts to be learned about any sedimentary bed or assemblage of beds and must be known to make the description of the beds complete. Very little evidence is available to indicate the thickness of the sedimentary members of the schist-gneiss group. Distinctive beds that could be used as horizon markers in correlating the rocks of one locality with those of another were not recognized. Furthermore, folding is intense and faulting is common, so that the measurement of thickness is difficult. Added to these difficulties are the facts that more than one period of geologic time may be represented by the beds and that the beds themselves have not been differentiated from the intrusives that invade them. The question of thickness is therefore a complicated one and at present 
can be answered only in approximate terms by saying that the schist derived from sedimentary beds probably represents many hundreds if not thousands of feet of deposits.

The metamorphic rocks acquired their characteristic structure while they were buried deep beneath the surface of the earth, where both temperature and pressure were great. They have since been elevated, and many hundreds or thousands of feet of overlying rock have been removed by erosion, thus exposing to view the lower beds and the granitic intrusives.

In parts of the area the cleavage of the fissile sedimentary rocks corresponds to the planes of the bedding; in other parts, however, it crosses the bedding at various angles, depending on the position in the folds, so that the angle between the bedding and cleavage may range from parallelism to $90^{\circ}$. Analysis of the structural observations made on the rocks throughout the district shows that the cleavage of the schist and the bedding planes of the sedimentary members have a strike that is prevailingly toward the north and west in the vicinity of the Delta River and Jarvis Creek and toward the north and east in the eastern part of the district, where strikes ranging from N. $45^{\circ}$ E. to N. $80^{\circ}$ E. predominate. The dips in the eastern part of the district are nearly all toward the south. Moreover the planes of drag folds in some exposures show an overturning of beds toward the north. Dips are less regular in the western part of the district, and both north and south dips were observed.

Faulting is common and in places has probably resulted in great dislocation of the rocks affected. Fault zones were seen in which the schist is highly disturbed and brightly colored with iron oxide, so that their courses could be easily followed on the mountain sides. Yet the absence of strongly contrasting beds, which by their offsets and interruptions might indicate dislocations more distinctly, makes the discovery of such structural features somewhat a matter of chance. Undoubtedly many faults were unnoticed for every one that was seen.

\section{AGE AND CORRELATION}

The age of the metamorphic rocks of the Gerstle River district is known only within wide limits. 'The sedimentary members, which when they were deposited may have contained fossils bearing evidence of their age, are too greatly altered to yield any such evidence now; and the only other beds so far discovered in the district that have any bearing on the age of the schist and of the gneiss derived from sedimentary beds were formed so late in the geologic time scale that their testimony gives little assistance.

The evidence available at present indicates that these rocks were deposited in middle or early Paleozoic or more probably in pre- 
Paleozoic time. They are regarded as being the westward extension of similar rocks exposed on the Robertson and upper Tok Rivers. ${ }^{2}$ In that district the evidence obtained indicates that the beds were formed before Middle Devonian time but gives no clue as to how long before. Mendenhall ${ }^{3}$ correlated the schist and gneiss of the Delta River with the Tanana schist, which was thought to be of pre-Silurian age. Tanana schist has since been abandoned as a formation name, and Birch Creek schist has been used for rocks that include the Tanana schist. Mertie ${ }^{4}$ has shown that two groups of ancient metamorphic rocks are present in the Yukon-Tanana region. The older consists of the Birch Creek schist and associated altered igneous rocks, of which the Birch Creek schist is considered to be of pre-Cambrian age but not late pre-Cambrian. The associated altered igneous rocks may range in age from pre-Cambrian to early Paleozoic. The second group of metamorphic rocks includes several formations, of which the lowest are considered to be of late pre-Cambrian age. The highest rocks of the second group range upward to the Lower Ordovician. Although a definite correlation of the metamorphosed sedimentary rocks of the Gerstle River district with any of the rocks described by Mertie is not yet warranted, some such correlation may eventually prove to be correct.

\section{PRE-TERTIARY IGNEOUS ROCKS}

\section{CHARACTER AND DISTRIBUTION}

Intrusive igneous rocks are present in wide variety within the Gerstle River district. As has already been pointed out they may be divided into two major classes depending on relative age, which in this connection is indicated by the presence or absence of regional metamorphism. The first class includes those that were intruded into the old sedimentary deposits and underwent distortion and recrystallization before the later intrusives invaded the sedimentary beds. They are made up in considerable part of acid types of granitic intrusives and probably represent different periods of intrusion. They are now so altered that their original characteristics are largely destroyed and for this reason were included with the schist and gneiss that have been described. The second class of intrusive igneous rocks includes those intrusives that were injected after the metamorphism of the older sedimentary and igneous rocks had taken place or at least was nearly completed. Some of them show slight alteration owing to pressure or chemical and mineralogical changes, and some appear

\footnotetext{
${ }^{2}$ Moffit, F. H., Geology of the Slana-Tok district, Alaska : U. S. Geol. Survey Bull. 904, pp. 13-15, 1938 .

3 Mendenhall, W. C., Geology of the central Copper River region : U. S. Geol. Survey Prof. Paper 41, p. 30, 1905.

- Mertie, J. B., Jr., The Yukon-Tanana region, Alaska: U. S. Geol. Survey Bull. 872, pp. $46-47,1937$.
} 
fresh. This suggests that they also may represent more than 'one period of intrusion. They are the rocks that will now be described.

The younger igneous rocks of the Gerstle River district include a variety of intrusives ranging from granular basic types to acid types. They have the form of dikes, sills, and stocks, or large bodies of irregular shape. Two principal areas of the larger bodies of intrusive are shown on the geologic map. One includes the flat-topped mountain mass facing the Tanana lowland between Jarvis Creek and the Gerstle River. The other extends from the high peaks east of Gerstle Glacier eastward across the Johnson River to the high tableland between the Johnson and Robertson Rivers. Although the eastern boundaries of this second area were not determined, they probably include most of the tableland between the high mountains and the Tanana River.

Only a few of the dikes and sills are shown on the geologic map. Such intrusives are numerous in the high mountains of the central part of the range and have supplied a large part of the material of the morainal deposits and the more resistant part of the flood-plain gravel of streams. The glaciers of the Gerstle and Johnson Rivers carry much material obtained from this source, but it is possible that they also derive some of their load from stocks or other large bodies in the almost inaccessible parts of the central mountain mass.

The large western area of igneous intrusives consists almost wholly of coarsely granular, light gray rock to which the field name granite may appropriately be applied, although in a strict petrographic sense much of it may be more accurately designated by names indicating types of more basic character, as quartz monzonite and granodiorite. Both these types of rocks are among the specimens collected by the writer and examined with the microscope by Robert Coats. This mass of intrusive granite produced extensive changes in the host rock by introducing contact-metamorphic minerals and otherwise altering the character of the rocks in the contact zone between the two. This contact-metamorphic change is notable on Granite Creek, where the schist near the boundary is hardened and highly colored through the weathering of disseminated pyrite, which probably was introduced at the time of intrusion. The contact in this vicinity, however, appears to be the locus of pronounced fault movements, so that the rocks are much disturbed.

The granite area in the eastern part of the district north of Mount Kimball is apparently considerably more extensive than that between Granite Creek and the Gerstle River, and it shows a wider variety of rock types. The main body of the intrusive mass is in the highland area between the Johnson and Robertson Rivers, but it extends westward to the high peaks at the head of the Little Gerstle River, where many dikes and sills mark the limits of the intrusion in that 
direction. Although most of the intrusive rocks in this vicinity are coarsely granular and light in color, heavy, dark basaltic rocks are present also and probabily belong to a later period of igneous activity than the light granitic intrusives.

From the head of the Little Gerstle River the boundaries of this granite area diverge rapidly toward the east so that they are separated by a distance of about 8 miles on the Johnson River. Here the rocks are dominantly of the light-colored granitic types. The section shown in the steep wall of the east side of the Johnson River Valley suggests that the intrusive body is a great lens or laccolite of granitic rock tilted toward the south, but whether this appearance resulted from erosion or indicates the actual form of the body was not determined. A glance at the topographic map (pl. 2, in pocket) will show that glacial erosion has left some striking topographic features in the highlands between the Johnson and Robertson Rivers. Much of this area is occupied by granite.

The great quantity of light-colored granitic boulders and cobbles carried by the Gerstle and the Johnson River glaciers suggests that this conspicuous rock waste may be derived from a source in the upper valleys capable of supplying a greater quantity of such material than the dikes and sills that cut the schist, but the difficulty of reaching the heads of the glaciers prevented the search for any such possible sources.

The dikes and sills are regarded as offshoots of the larger bodies of granitic rock that probably underlie much of the area. They are more conspicuous and seemingly more numerous in the higher mountains than in the tableland area, but this appearance may be due to the more favorable conditions for observation rather than to larger numbers.

Both light granitic dikes and dark basic dikes are present. Many of the light granitic dikes are porphyritic and show large phenocrysts of feldspar in an even-grained ground mass sufficiently coarse to permit easy recognition of the minerals that compose it. Feldspar crystals ranging from 6 to 8 inches in length and up to three-fourths of an inch in thickness were found. However, at this same locality crystals showing sections $1 \frac{1}{4}$ inches by $5 / 8$ inch, oriented in parallel lines on the rock face, were much more common. In contrast to these coarse-grained dikes are dikes of finer grain composed chiefly of feldspar and quartz. Many such dikes stand out because of the contrast in color between them and the host rock, and their courses over the mountainside are easily traced.

Dark fine-grained dikes are less likely to be noticed. Dikes of this kind were seen principally in the vicinity of the Johnson River, where they intrude the schist. Near the head of the small stream that joins the Little Gerstle River at the Hajdukovich hunting lodge, dikes of 
black medium-grained rock up to 10 feet thick crop out in the creek channel. The rock weathers into blocks with rounded edges and is much stained with iron oxide. It was identified by Robert Coats as quartz diabase.

\section{AGE OF THE INTRUSIVES}

Evidence for the age of the intrusive rocks of the Gerstle River district must be supplemented by testimony from other sources than those derived from the district itself if the assigned limits of age are to be restricted as.much as possible. The older intrusives, which show regional metamorphism, were intruded at a time or times prior to the formation of the Alaska Range. That orogenic movement is now generally regarded as having begun late in Mesozoic time and as having continued into the Tertiary. Probably the oldest intrusives were not only older but much older than the beginning of the moveinents that produced the range. The later intrusives, those which did not undergo regional metamorphism, are later than the operation of the forces that caused the metamorphism. They intrude the metamorphic rocks and probably were involved with them in the growth of the range, for insofar as is known at present none of them cut the Tertiary coal-bearing beds exposed in the Gerstle River district. Since they are deep-seated rocks and were formed at great depths they could have been exposed at the surface only after a long period of erosion that preceded the laying down of the Tertiary beds.

Mertie ${ }^{5}$ has pointed out that five principal epochs of igneous intrusion have been recognized in the Yukon-Tanana region. Two of these are pre-Paleozoic, and of the remaining three, one belongs to the Paleozoic, one to the Mesozoic, and one to the Tertiary. In the Nabesna district granitic intrusives have invaded the Lower Cretaceous slate and graywacke of the Nutzotin Mountains, but their precise age is not known. Whether they are of late Mesozoic or early Tertiary age has not been determined.

The absence of Mesozoic rocks on the north side of the Alaska Range in the Gerstle River district offers a difficulty that so far has prevented correlation of the intrusives there with those of the nearby Yukon-Tanana region or of the eastward continuation of the range. If they are to be correlated with the intrusives of any of the five epochs mentioned by Mertie it would probably be with those of the Mesozoic epoch, because if they were older they probably would show greater metamorphism and if they were younger some suggestion of their youth might have been found in the coal-bearing area; but more significant than this, they probably would not show as much alteration as they show and would appear fresher than they appear now.

'5 Mertie, J. B., Jr., The Yukon-Tanana region,-Alaska: U. S. Geol. Survey Bull. 872, pp. 198-201, 1937: 


\section{TERTIARY COAL-BEARING ROCKS}

\section{CHARACTER AND DISTRIBUTION}

A small part of the country under consideration is occupied by sedimentary rocks of fresh-water origin and Tertiary age. The total area is only a few square miles, although it probably was much more extended at one time than now. The principal area of the Tertiary rocks and in fact the only area that could be mapped with fairly accurate boundaries includes the top of the ridge between the Delta River and Jarvis Creek and extends southward 5 miles from the saddle west of the head of Little Gold Creek to the sag in the ridge east of Donnelly Station, through which the trail between the two streams passes.

The rocks of this area cover about 12 square miles, as nearly as can be told from the rather inadequate outcrops on the ridge, and include soft yellow and buff shale or clay, gray and yellowish sand beds, clean white quartz grit and sand, and coal beds. The best exposures are on the west side of Little Gold Creek Valley, on the western tributary of Jarvis Creek that comes in below the mouth of Little Gold Creek, and on the creek, locally known as Sargent Creek, that flows east from the saddle at the north end of the area of Tertiary rocks. Much of the area is covered by a mantle of gravel-morainal and other unconsolidated material-so that the exact boundaries between the metamorphic and the younger rocks are not known. This uncertainty is particularly true of the west boundary.

The Tertiary rocks are present in other localities as is shown by the fragments of coal in the creek gravels, but outcrops of these rocks in place were not recognized. One such locality is crossed by the trail that leads eastward over the hill from the mouth of Riley Creek. Probably Tertiary deposits are also present farther north on Jarvis Creek and east of Macomber Creek. The Tertiary rocks are soft and weather rapidly, so that they are easily removed completely or are concealed by vegetation and by the mantle of loose rock fragments.

\section{THICKNESS AND STRUCTURE}

Little Gold Creek and the small unnamed creek west of it give excellent opportunities for examining the coal-bearing beds. In both places the beds are not greatly disturbed and in general are nearly horizontal, although farther north on Sargent Creek they dip at various angles up to $40^{\circ}$. The mountain slope on the west side of Little Gold Creek Valley shows no other rocks except those in the practically horizontal beds of the coal-bearing group, and it gives the section of greatest thickness known in that area. No faulting that might complicate the structure was seen. It therefore appears that the 
maximum thickness of beds in this vicinity is probably not less than 1,200 feet, for it practically corresponds with the difference in altitude between the channel of Little Gold Creek and the top of the ridge on the west. The next creek toward the west gives a splendid section of beds having a thickness of approximately 600 feet. This is less than the apparent thickness on Little Gold Creek; but the basement rocks are not exposed and the ridge at its head is not so high. Sargent Creek does not afford a good section for measuring thickness. It exposes coal and some of the associated sand and conglomerate but has not cut into them deeply enough to furnish a favorable section for measurement. However, the exposures there indicate that the beds thin out toward the north margin of the area.

The coal-bearing beds rest unconformably on the old schist and gneiss. The basal beds are clean white quartz sand and grit. The quartz fragments are angular and are particularly well sorted, ranging in size from coarse sand to pieces possibly 3 inches in greatest diameter. The prevailing size, however, is from a quarter of an inch to 1 inch. Many of the larger fragments are water-worn, but not the small pieces. The two notable characteristics of the material are the angularity of the fragments and the assortment into beds, in which fragments of approximately the same size predominate. Although the material is not consolidated it is compacted and stands in the outcrop with vertical face so that a pick is needed to loosen it. For this reason it weathers into peculiar forms, notably those of mushroom shape, with a more or less columnar base and an expanded cap, which is the remnant of a slightly harder overlying bed (pl. $6, A$ ).

The thickness of the basal quartz beds varies greatly from place to place. At the head of Little Gold Creek it is at least 100 feet, but elsewhere it is much smaller. Possibly the quartz is absent in places. Above the white quartz beds follow beds of clay, sandy shale, sandstone and sand, grit and conglomerate-all interstratified with beds of lignitic coal ranging in thickness from a few inches to 10 feet. Near the base of the section sandstone beds containing concretions 4 feet in diameter were seen. A notable feature of the clay and shale beds is the abundance of fine mica scales such as are found in the mud and fine sand of the present streams coming from the areas of metamorphic rocks. They, like the white quartz fragments, are a product of the weathering of the schist and gneiss. Most of the sandstone and shale beds are yellowish or buff-colored. Many beds show cross bedding and like the sand beds are of lenticular form. Many contain the fragmental remains of plants.

The basal white quartz member and the many beds of coal are the most outstanding features of the Tertiary deposits. In the saddle between the head of Little Gold Creek and the Delta River a coal 
bed 10 feet thick overlies sandy shale and sandstone, which in turn overlie the white quartz beds (pl. 6, B). Another thick bed of coal crops out on the brow of the ridge north of the saddle, and midway between the two coal beds is a third bed 4 feet thick.

The full section of coal-bearing beds on Little Gold Creek was not measured, but a partial section as shown in the small pointed hill on the west side of Little Gold Creek, 3 miles above the mouth, was examined with some care. The beds here represent the base of the group. They lie horizontally, and some of them can be followed all the way around the hill. The section is as follows:

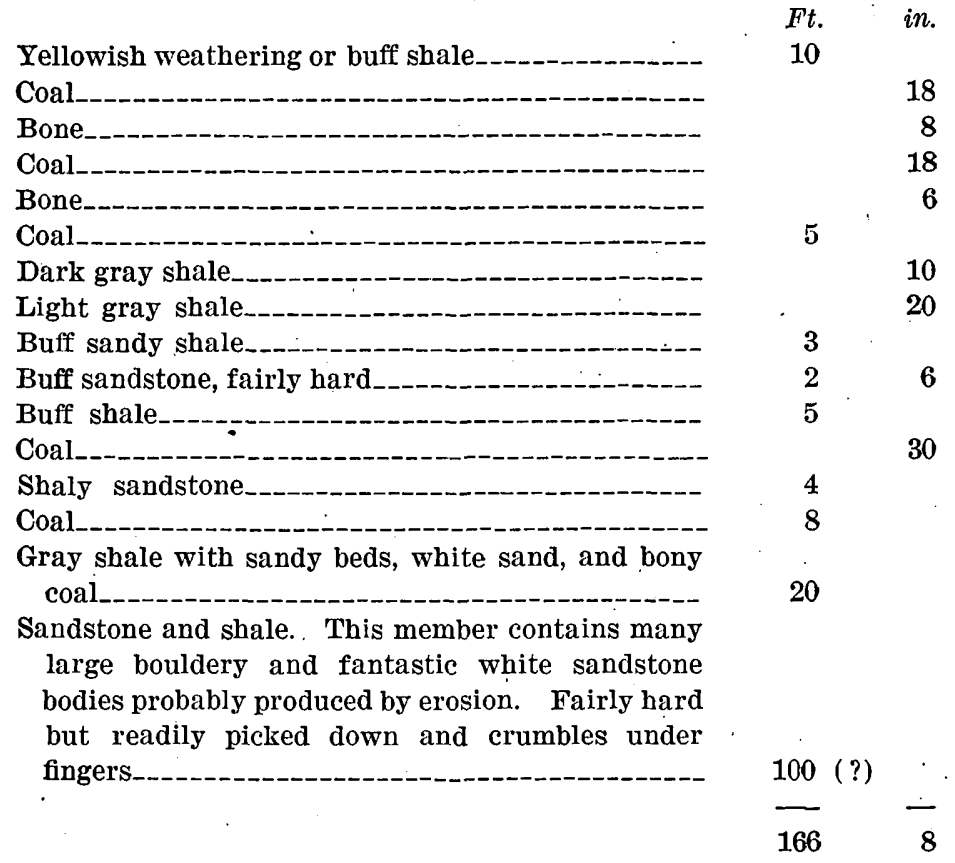

Probably not fewer than 20 beds of coal, ranging from a few inches to 8 feet in thickness, are exposed in the west wall of the basin at the head of the short creek west of Little Gold Creek (pl. 7, $A$ ). The stratigraphic section there comprises at least 600 feet of beds, as has been noted above. Two thick beds of coal-one 8 feet, the other 7 feet-crop out near the base of the exposed section. A third bed, 4 feet thick, crops out near the middle; and a persistent fourth bed; 3 feet thick, is exposed near the top. The many thinner beds are distributed throughout the section.

On Sargent Creek no continuous section of the coal-bearing beds is exposed. The creek runs nearly east from the saddle in the ridge and exposes the beds intermittently for a distance of about 1,500 feet east from the axis of the ridge. The beds rest on schist and dip toward the southwest. The basal white quartz bed is not uncovered 
at the schist boundary but is evident by an abundance of angular quartz fragments in the creek at this point. On going west up the stream bed a short distance one first finds evidence of an unexposed coal bed. A few yards farther upstream a bed of poor coal, 4 feet thick, with southwesterly dip, appears. Then follow beds of hard bluish-gray grit and fine conglomerate with a maximum dip of $40^{\circ}$ SW. About 1,000 feet upstream from the schist boundary a horizontal bed of coal, 4 feet thick, is underlain by iron-stained clay containing mica in fine scales, and overlain by soft; finely banded, yellowish sandstone. This bed of coal continues upstream about 300 feet but is uncovered in only a few places. No further exposures appear along the creek above the coal outcrops.

\section{AGE AND CORRELATION}

Fresh-water deposits of Tertiary age are widely distributed in Alaska. They nearly everywhere include many beds of lignitic coal, so that beds of this kind are almost automatically assigned to the Tertiary system without much questioning, although the supporting evidence of fossils is always sought. The shale and sandstone of Iittle Gold Creek unfortunately are not material from which to make good fossil collections; yet some beds contain fragments of plants that leave no doubt regarding the age of the sediments themselves. A small collection of fossil plant fragments was made from the freshwater shale and sandstone of the small hill on the west side of Little Gold Creek described on pages 128-129. This collection was referred to R. W. Brown for identification and determination of age. Although the specimens were poor, Brown identified three of the forms tentatively as follows: Glyptostrobus europaeus (Brongniart). Heer, Alnus sp., and Fagus antipofi Abich. He says of them, "There is no doubt of the Tertiary age of these fossils, but knowledge of the Alaska Tertiary floras is not yet sufficiently detailed to permit a more precise statement of age." This statement is a general one applying to many other districts as well as to the Gerstle River district. Until recently the fossil plants have been regarded as indicating an Eocene age for the coal-bearing beds, but, as will be seen later, the discovery of fish remains in members of the series now suggests a Miocene age for some of them.

It is unnecessary to make references to all the various Tertiary coalbearing formations with which those of the Gerstle River district might be correlated. In view of the statement by Mr. Brown it is evident that the deposits of the different areas are not necessarily contemporaneous but may possibly be distributed through different parts of the Tertiary system. It may be pointed out, however, that Tertiary deposits are present on both sides of the Alaska Range within 
the drainage basin of the Delta River and that they are extensive on the north side of the range farther west in the Nenana coal fields. Capps ${ }^{6}$ has shown that they also occur in many isolated areas along the north front of the range between the Nenana and Delta Rivers. This distribution, together with the character of the deposits, makes it appear probable that, at least within this region, the beds were laid down contemporaneously, or essentially so.

\section{UNCONSOLIDATED DEPOSITS}

\section{NENANA GRAVEL}

\section{CHARACTER AND DISTRIBUTION}

At several places in the Gerstle River district deposits of gravel are exposed that are evidently not a part of the present stream gravels and almost as evidently cannot be classed among the deposits of glacial origin. They appear in small isolated areas within or at the margin of the highland area between the central mountain mass and the Tanana lowland. In places these gravel deposits are unconsolidated but elsewhere are slightly cemented. Moreover, the slightly cemented deposits commonly have a yellowish color, which distinguishes them from those that are uncemented. These circumstances may raise some doubt as to whether the two are to be correlated with each other, but, in the absence of definite evidence to the contrary, it has seemed best to consider them together and provisionally to regard them as belonging to the same formation. The principal localities of these deposits are in the valley of Macomber Creek or adjacent to it and at the north border of the highland area west of the Gerstle River. Possibly the gravel deposits at the canyon of the Gerstle River (pl. 8,A) and on the east side of Jarvis Creek opposite the north end of the Tertiary coal-bearing beds may also belong in part to this same group of gravel deposits, which are here tentatively correlated with the Nenana gravel. The deposits of Macomber Creek will be considered first.

Two northward-flowing tributaries join Macomber Creek a short distance below the mouth of Old Channel Creek and in their lower courses flow for a mile or more through narrow canyonlike valleys cut in yellow gravel deposits. These deposits are best seen at the mouth of the eastern stream, where a section over 100 feet high is exposed (pl. 7, B). The top of this section consists of gray bouldery glacial wash containing a large proportion of angular schist fragments. The lower 60 feet is yellowish-gray gravel in which are lenses and beds of hard yellowish-gray sandstone in practically horizontal

\footnotetext{
${ }^{6}$ Capps, S. R., The Bonnifield region, Alaska: U. S. Geol. Survey Bull. 501, geologic map in pocket, 1912.
} 
position. The sand beds in this particular section reach a thickness of 30 inches. They consist mostly of quartz grains of fairly uniform size and contain a small proportion of well-rounded pebbles sparingly scattered through them. The gravel beds are made up of pebbles and cobbles of granite and quartz contained in a sand base, which is slightly compacted but can readily be picked down with the hammer. Few of the cobbles exceed 8 inches in diameter. All are well-rounded and those of granite are so much decomposed that they are easily mashed with the flat side of the hammer. The granite in the sandstone lenses is harder than the sandstone, however, which although yellowish on the weathered surface is gray on the unweathered freshly broken surface. The quartz, in contrast with the granite, is hard and resists weathering, although quartzose cobbles derived from some gneissic rock are easily broken. The colors of the quartz cobbles are gray and white. Most of them are smooothly rounded, and many present an especially attractive appearance when wet. Some are banded and look like agate.

Exposures of the yellowish gravel continue up the creek for nearly 1 mile, but as the channel of the creek rises the thickness of yellow beds in sight diminishes and the proportion of overlying glacial wash increases. Gravel deposits of the same kind appear in the banks of Macomber Creek above Old Channel Creek, but there they are less favorably exposed for observation. It is highly probable that these deposits are much more widely distributed than these areas indicate, as the covering of glacial wash and vegetation permits them to be seen only in favorable places.

The yellow gravel with overlying gray glacial wash continues down Macomber Creek for 1 mile below the mouths of the two streams previously referred to, where a small gulch joins Macomber Creek from the northeast. This gulch exposes extensive gravel deposits, which are best developed on the lower slope of the hill to the north, where they extend more than 200 feet above the little creek and form a conspicuous landmark because of the contrast between their color and that of the bedrock and vegetation of the hill. These deposits do not have a pronounced yellow color but are yellowish white or lack the yellow entirely. They consist of decomposed granite and wellrounded quartz pebbles, many of which have a distinctive greasy luster on the fresh surface. Their bedding was not determined, for the gravel in place is covered by the loose material that mantles the hill slope.

Two miles west-southwest of the mouths of the same two tributaries of Macomber Creek a prominent low hill marks the highest point of the ridge between Macomber and Jarvis Creeks. This hill is formed of well-washed gravel containing smoothly worn pebbles and cobbles 
of granite and quartz up to about 6 inches in diameter, although most of the material is smaller. The greasy-looking quartz, like that just inentioned, is present here also, and the similarity between this gravel and that described in the paragraph above is such as to leave little doubt that they are to be correlated with each other.

The old trail between the Gerstle River and the Richardson Highway south of Beales Cache crosses a small creek 2 miles west of the river. This creek and the two branches of the next one on the west extend southwestward into the upland area and are separated from one another by narrow ridges. The points of these ridges and of the ridge east of the first creek are made up of bedded gravel deposits that dip steeply north-northeastward (pl. 8, $B$ ). When first seen these gravel deposits appeared to be part of the material spilled over the ridge on the east by the old glacier that formerly occupied the valley of the Gerstle River, but, on being closely examined, they showed that they are distinctly bedded gravel consisting largely of well-rounded quartz and granite such as was not seen in any of the deposits of undoubted glacial origin. This locality gives the best example of regularly bedded, steeply dipping gravel beds seen during the field season. The thickness of the deposits was not measured, but it amounts to many hundreds of feet. Such tilted beds are typical of the Nenana gravel in its type locality.

\section{STRUCTURE}

All the gravel deposits here considered as belonging to the Nenana gravel formation rest unconformably on the ancient metamorphic rocks wherever their relation to the underlying rocks is known. The question of their structural relation to the Tertiary coal-bearing beds therefore can hardly be determined from this district as no exposures of the two formations in contact or near each other are known. Seemingly, the beds themselves are either horizontal or only moderately tilted except in the locality at the margin of the highland area near the Gerstle River, where the dip approaches $40^{\circ}$ north-northeast.

\section{AGE}

The exact age of the Nenana gravel has not yet been determined. The formation is widely distributed along the north front of the Alaska Range, but its type locality and most conspicuous exposures are in the vicinity of the Nenana River, from which it takes its name. It has been described by various writers, but chiefly and most recently by Capps, ${ }^{7}$ who proposed the formation name originally and who has summarized the facts and opinions regarding it. It is un-

\footnotetext{
7 Capps, S. R., Geology of the Alaska Railroad region: U. S. Geol. Survey Bull. 907, pp. 123-128, 1940.
} 
necessary to repeat this summary further than to state the conclusions which at present seem most probable. Information obtained from the Gerstle River district extends the known distribution of the Nenana gravel but contributes little to a knowledge of its age.

Up to this time the Nenana gravel has not yielded fossils from which its age can be determined, but its stratigraphic relations furnish a measure of information about its age. In most places, but not everywhere, the gravel rests with structural conformity on the beds of the Tertiary coal-bearing formation. It is therefore younger than the coal beds. As the Nenana gravel deposits were deeply eroded, wide valleys were formed in them before the advance of the earliest recognized Pleistocene glaciers. It is therefore older than the glacial deposits. This difference of age is further indicated by the advanced decomposition of the granite cobbles and the discoloration of the deposits as contrasted with the unaltered state of the glacial deposits.

One of the principal differences between the Nenana gravel and the conglomerate of the Tertiary coal-bearing formation is the greater coarseness of material of the Nenana gravel, a difference that is thought to be due to a revival of vigorous erosion brought about by renewed uplift of the Alaska Range and the resulting rejuvenation of its streams after the coal beds were formed. The unconformity, which in some places occurs between the coal beds and the Nenana gravel, is regarded as a local condition due to local causes-possibly to the overlapping of older beds by younger beds as the area of deposition widened or to the erosion and redeposition of the original beds by later streams. Capps believes that deposition of the coal beds and the Nenana gravel was a practically continuous process marked only by the rejuvenation of the streams, which provided the coarser material of the younger formation, and that the two formations were folded and tilted together. Such a conclusion, if it is correct, leaves the determination of the age of the Nenana gravel dependent on a knowledge of the age of the Tertiary coal and associated deposits. For many years the age of the coal-bearing formation has been regarded as Eocene, as determined from the study of fossil plants. However, the discovery of fish remains in beds belonging to the coal series by Schlaikjer ${ }^{8}$ in 1936 and his determination of their age as Miocene casts some doubt on the earlier determination. Until this doubt is cleared away the age of the coal beds and the Nenana gravel will not be known definitely; yet there can be little question that the Nenana gravel was deposited during the Tertiary period.

\footnotetext{
${ }^{8}$ Schlaikjer, E. M., New fishes from the continental Territory of Alaska: Am. Mus. Nat. History Bull., vol. 74, art. 1, pp. 1-23, 1937.
} 


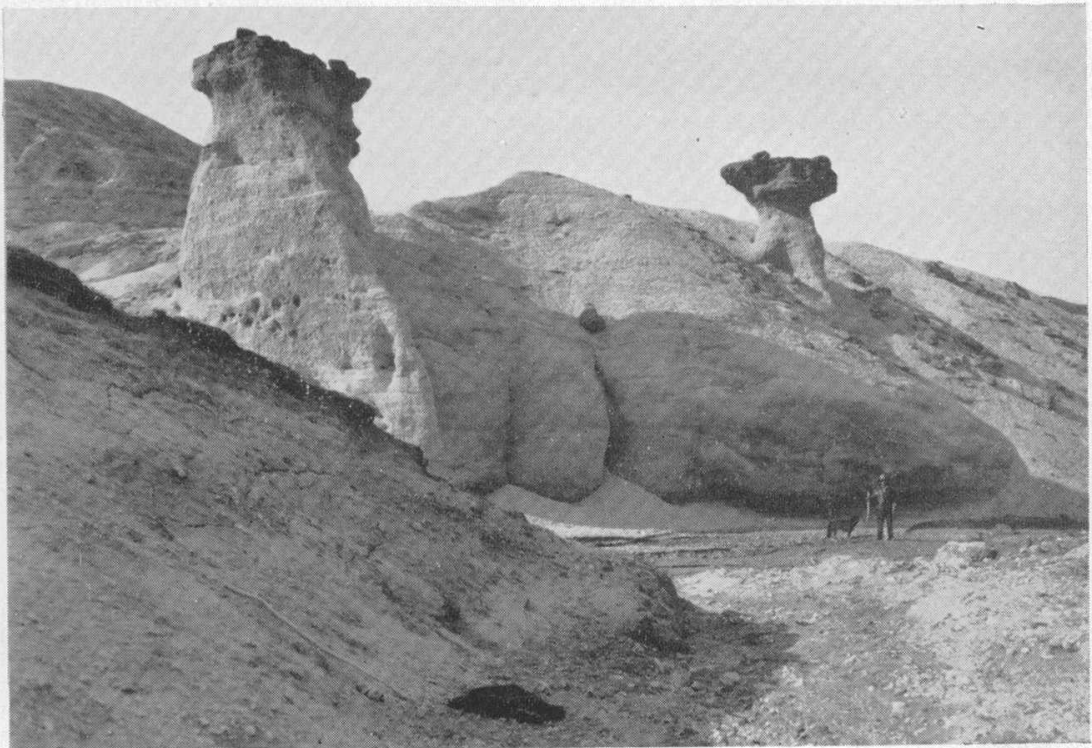

A. BED OF WHITE QUARTZ FRAGMENTS AT BASE OF TERTIARY COAL-BEARING DEPOSITS NEAR HEAD OF LITTLE GOLD CREEK.

The peculiar mushroomlike forms resulting from erosion are due to differences in compactness or cementation.

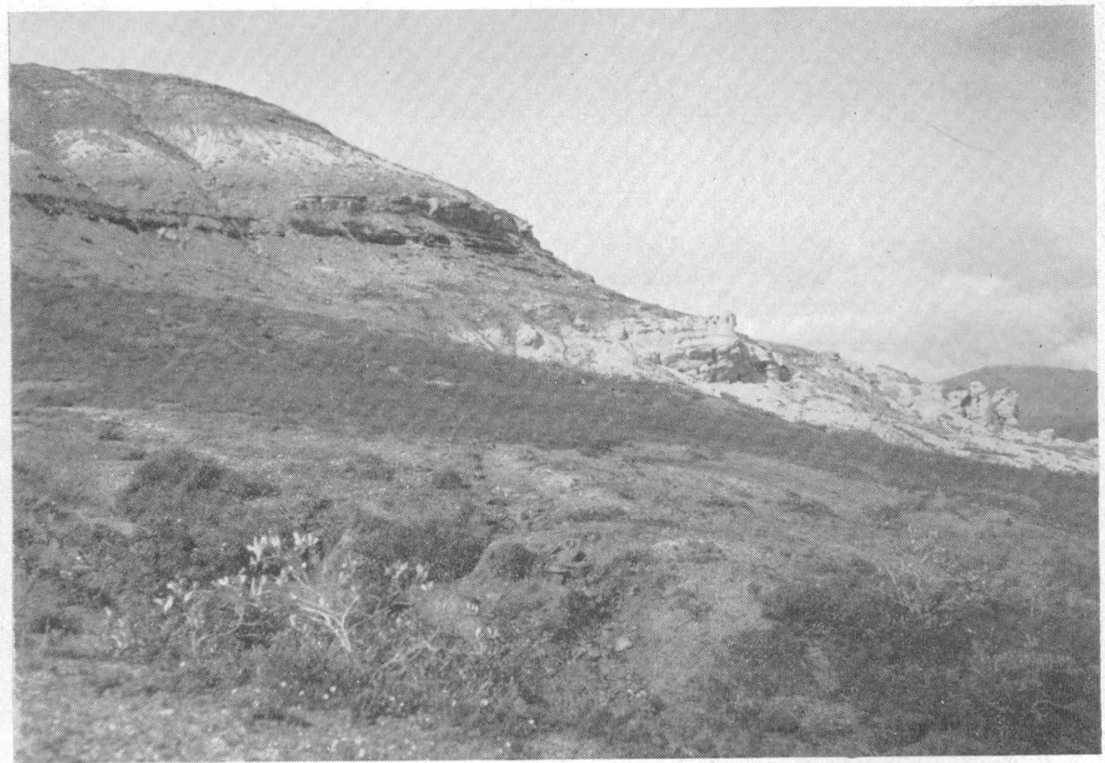

B. WHITE QUARTZ BED THAT FORMS BASE OF TERTIARY DEPOSITS NEAR HEAD OF LITTLE GOLD CREEK.

The dark ledge above the quartz at the left is a bed of coal overlain by sandstone. 


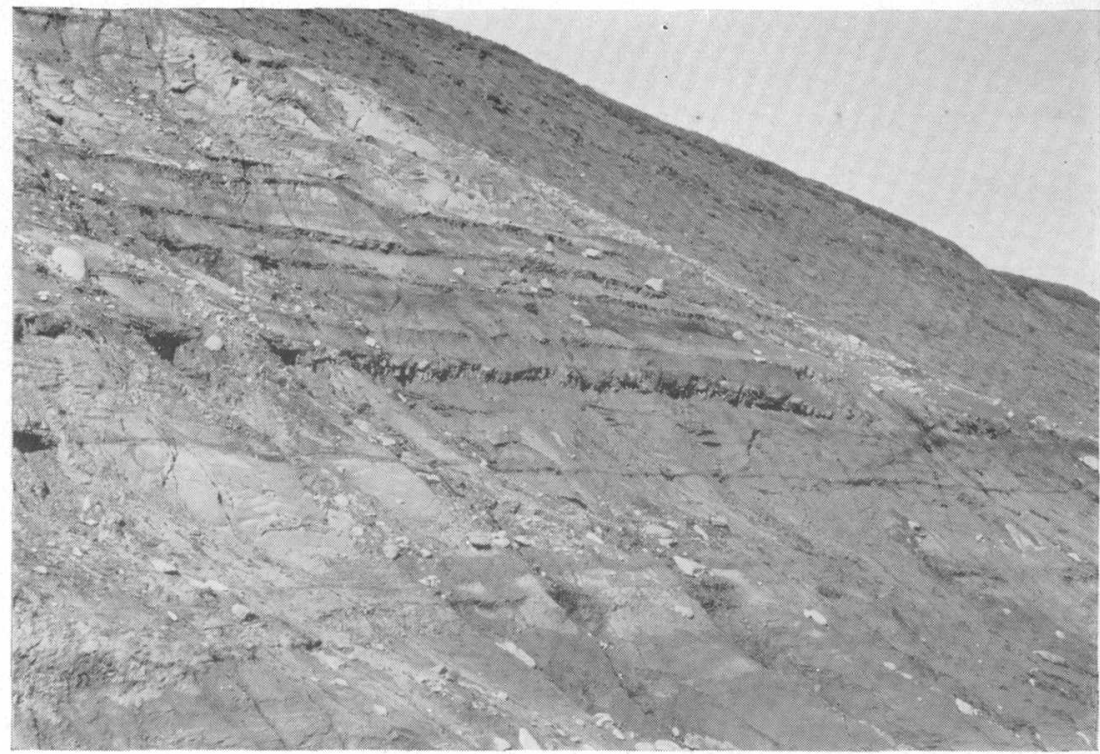

A. BEDS OF COAL IN SANDSTONE AND SANDY SHALE ON SMALL TRIBUTARY OF JARVIS CREEK WEST OF LITTLE GOLD CREEK.

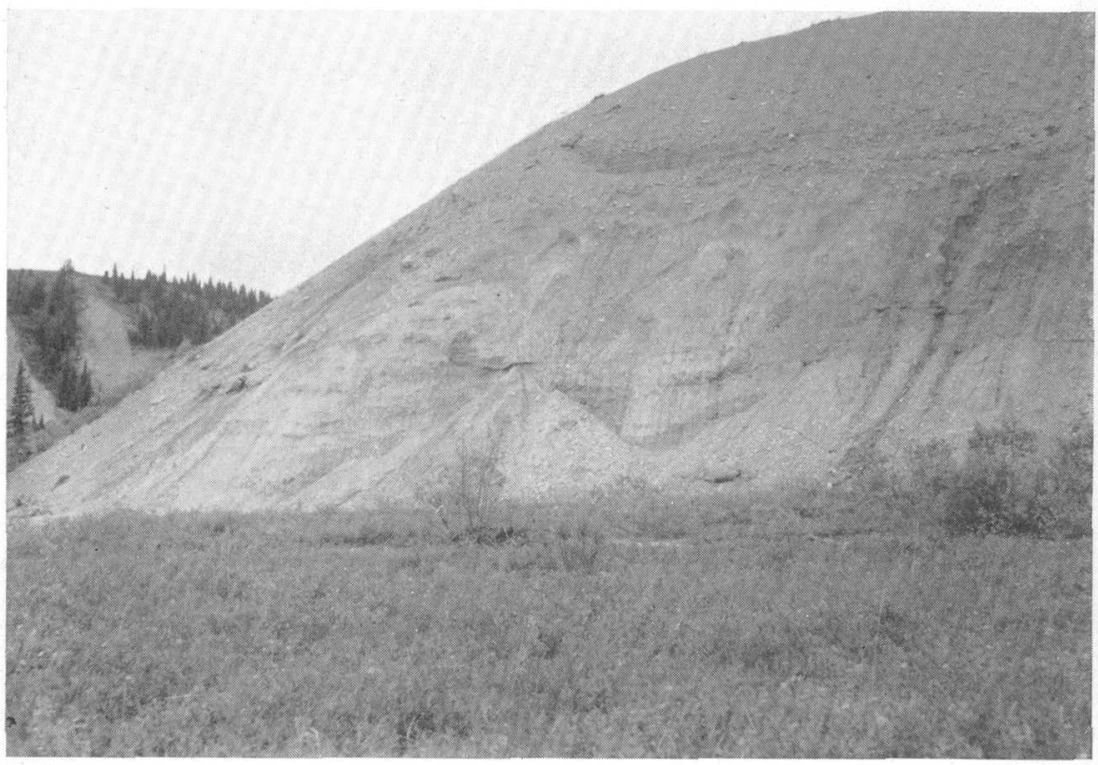

B. NENANA GRAVEL ON MACOMBER CREEK A SHORT DISTANCE BELOW MOUTH OF OLD CHANNEL CREEK. 


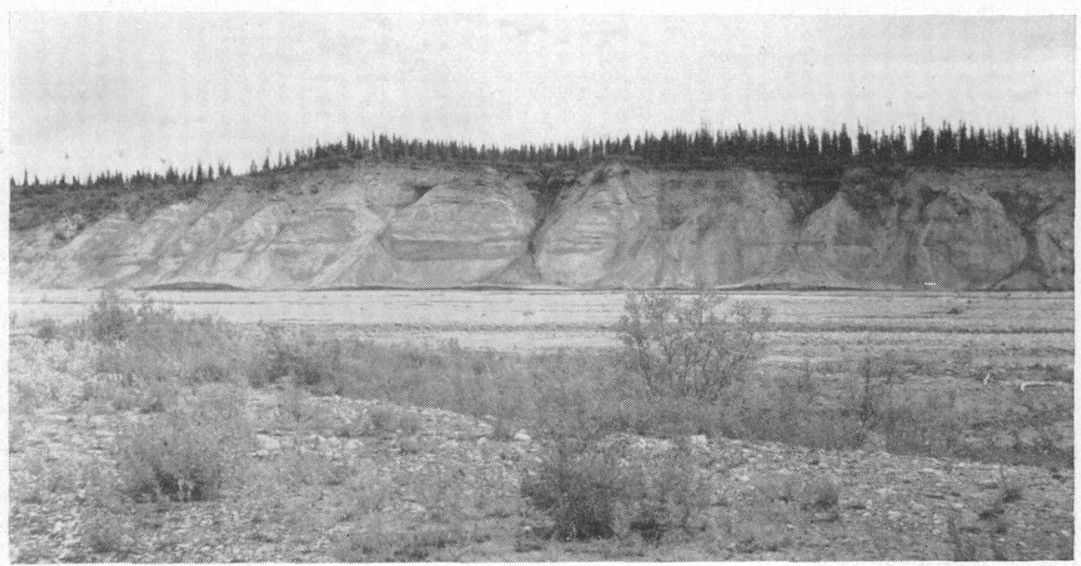

A. GRAVEL DEPOSITS ON EAST SIDE OF GERSTLE RIVER NEAR THE CANYON.

Probably Nenana gravel with some glacial outwash overlain by wind-blown sand.

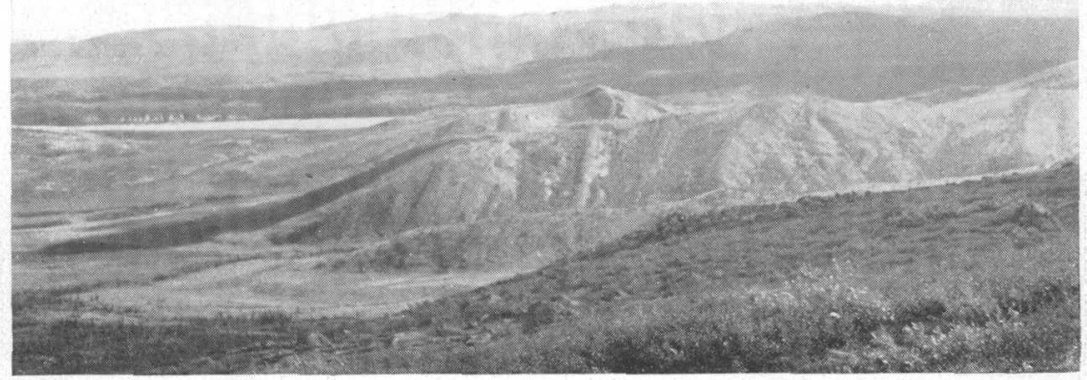

B. TILTED GRAVEL BEDS (NENANA) NEAR MARGIN OF HIGHIAND AREA WEST OF GERSTLE RIVER.

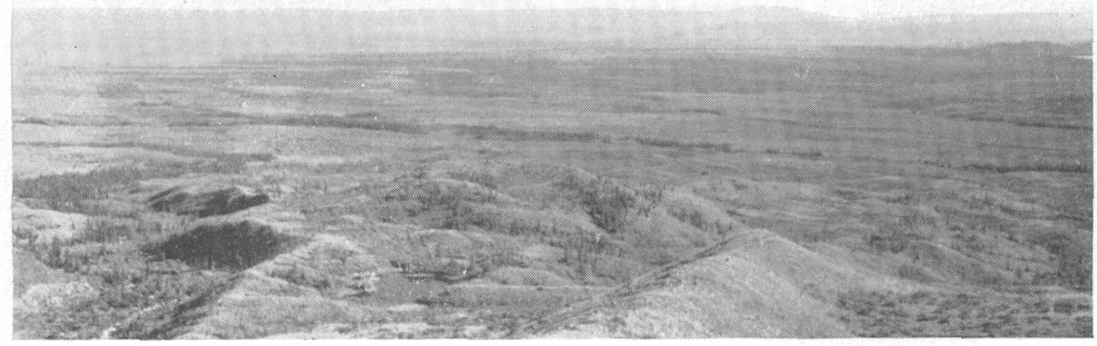

C. MORAINAL DEPOSITS AT MARGIN OF TANANA LOWLANDS 8 MILES NORTHWEST OF GERSTLE RIVER.

The small glacier that formed them has long since disappeared. 


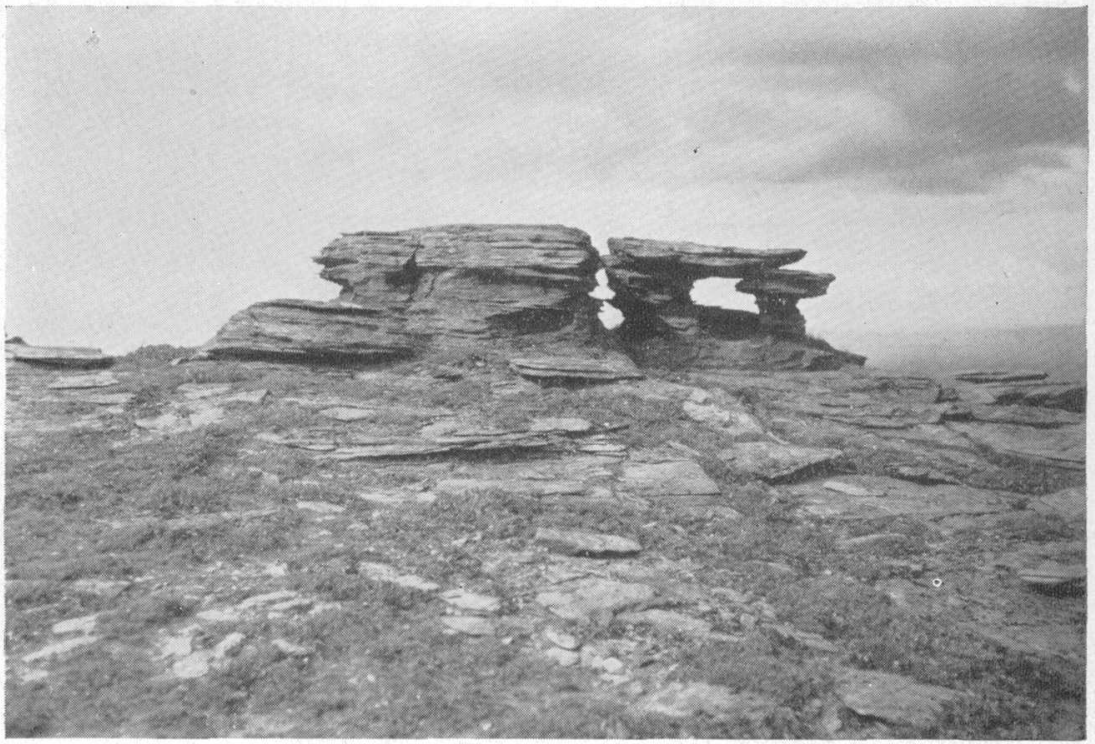

A. WEATHERED MASSES OF SCHISTOSE GRANITE ON RIDGE WEST OF GERSTLE RIVER, $21 / 2$ MILES NORTHEAST OF BRADFORD CREEK.

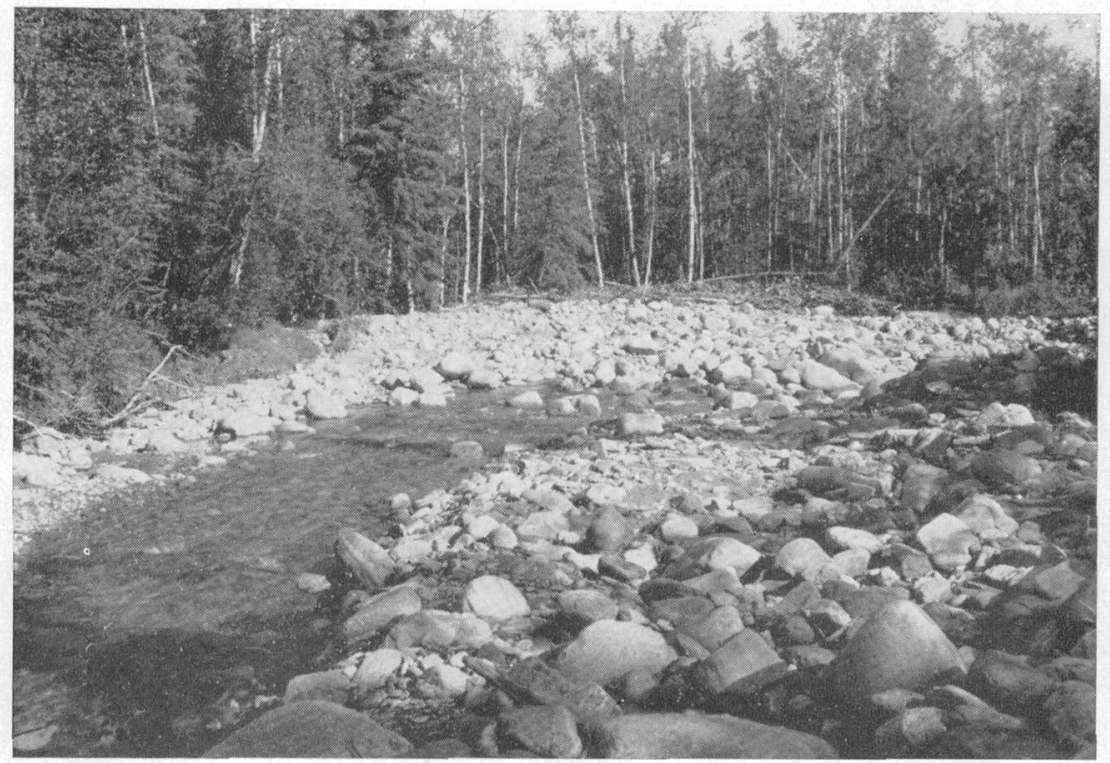

B. BOULDER-STREWN BED OF SHEEP CREEK.

These granite boulders are not native to the valley but were brought here hy glacial ice. 


\section{MORAINAL DEPOSITS}

All the larger streams and many of the smaller streams of the Gerstle River district have glaciers at their heads. Formerly these glaciers were much larger than now so that the main bodies of ice extended out into the Tanana lowland area. Furthermore, the valley of the Delta River was one of the outlets for glacial ice that accumulated south of the Alaska Range, where the whole of the Copper River Basin was filled to a depth of several thousand feet. These bodies of moving ice either contained or bore upon their surfaces vast quantities of rock waste, which they carried from the higher to the lower levels and deposited in confused heaps near their margins or strewed over hills that were gradually exposed as the ice receded. Yet probably the greatest proportion of the material carried by the glaciers was delivered to the streams coming from the melting ice or resulting from direct precipitation and was distributed in the wide outwash plains that occupy the Tanana lowland area. However, attention will be given here to the glacial moraines, which are typically glacial deposits, rather than to the outwash plains, which are stream deposits.

Morainal deposits, like normal stream deposits, are formed from the waste material produced by weathering and erosion. Their composition therefore depends on the kind of bedrock in the area from which they came. The blocks and fragments of rock in such deposits are mostly angular or subangular, and because they have undergone less rolling and grinding than stream gravel they tend to show a smaller proportion of hard resistant rocks like quartz. The morainal deposits of the Gerstle River district are made up of schist, gneiss, granite, quartz, and representatives of all the rocks of the area from which they were derived. They were left as jumbled heaps and crooked ridges of unsorted rock fragments, separated by depressions many of which contain ponds and small lakes. As the ice did not move far out on the lowlands, the morainal deposits are most abundant near the places where the streams leave the highland area. On the east side of the Delta River Valley they cover much of the valley bottom except the present river flood-plain from Donnelly Station northward to a line running northwestward from Beales Cache to the river and southeastward to Granite Creek.

The boundaries of the morainal areas commonly have a lobate form, which indicates the way the ice spread when it was no longer confined by the valley walls. This is well-illustrated by the Delta River moraines. The same lobate form is seen on the Gerstle and Little Gerstle Rivers and on the Johnson River. The moraines of the Johnson River Glacier extend to the Tanana River and probably beyond. Between Jarvis Creek and the Gerstle River several lobate areas of moraine (pl. 8, $C$ ) mark the places where small streams come out of the granite 
area. Although at one time these streams had local glaciers at their heads that supplied material for the moraines, the main ice sheet also may have extended over the granite area from the south and contributed its share of the debris.

The boundaries of the glacial deposits were not mapped in detail, but in a general way the distribution of the areas near the Delta River and Jarvis Creek is, shown on the geologic map (pl. 3). Between the big Gerstle and Johnson Rivers, where a great quantity of material was left, the deposits possibly extend well beyond the Tanana River; for, as viewed from a distance, certain low hills opposite the mouth of the Little Gerstle River appear to be morainal, as do other hills on the west side of the Tanana River below the Little Gerstle. The particular interest of these areas of moraine is that they show the limit of the most recent glaciation. This limit is but little beyond the highland area and indicates that a great difference in conditions favorable for the accumulation of ice must have existed north and south of the Alaska Range.

The glacial deposits described so far are those of the lowland areas; yet deposits left by the ice are not confined to the low country. They appear at much higher altitudes, although in smaller quantity, and are found on ridges 2,000 feet above the Delta River. West of the Little Gerstle, erratics are scattered over hilltops 1,600 feet higher than the river, and on the east side they were seen 1,000 feet above the stream. The more conspicuous evidences of the higher deposits are granite erratics and streains of granite blocks or boulders that evidently were left by ice moving away from the high mountains. However, the ridges of the highland area between the higher part of the range and the Tanana lowland were not completely buried, at least not during the most recent advance of the ice, for some of them bear weathered outcrops of rock of such a form that they would surely have been swept away by even a thin sheet of moving ice (pl. 9, $A$ ).

The distribution of glaciers that is indicated by the morainal deposits gives a picture of former snow fields and ice streams that were of far greater extent than those of the present. Then only the higher peaks and ridges were exposed to view. The larger streams moved out from those valleys that penetrate most deeply into the heart of the range and not only filled them but straightened and enlarged them by their erosive power. Many spilled over their confining ridges into the smaller neighboring valleys, where the accumulation of snow was less. In this way the gravel deposits of some streams like Sheep Creek acquired a component of rock, particularly granite (pl. 9, B), which is not present in the bedrock of the valley itself. Such an overflowing from one valley into another is plainly recognized in many places.

The granite boulders and blocks of the higher moraines, like those of the lowlands, are partly fresh and partly deeply weathered. 
Whether this difference of alteration, which the granite fragments so often exhibit, indicates the ocurrence of two stages of glaciation widely separated in time or shows that the granite was derived from two different sources, such as the original rock in place on the one hand and the weathered material of the Tertiary gravel deposits on the other, is difficult to determine with the evidence at hand.

\section{STREAM DEPOSITS}

The unconsolidated deposits of gravel, sand, and silt that were laid down by the post-Tertiary streams or deposited in contemporaneous ponds and lakes require only brief attention. As a convenience in description they may be divided into deposits laid down by the more abundant waters from melting glaciers during a time of greater extension of the ice and into deposits formed by the present streams or lakes. The difference between them is more a matter of age than of composition or structure. The first includes outwash gravel, which is widely distributed along the edge of the Tanana lowlands but which can hardly be differentiated from stream gravels that have no connection with glaciers. The second comprises the flood plains of the present streams and the low terraces adjacent to these flood plains. Undoubtedly also some deposits formed in ponds and lakes are present but are subordinate to the stream gravels. No attempt is made to distinguish such deposits on the map.

In going northward over the Richardson Highway in the vicinity of Donnelly Dome the traveler passes first through an area of moraines and then, near Beales Cache, enters the true lowland area of the Tanana Valley. This part of the lowland is a plain sloping gently northward and showing little relief except where the streams have cut into it. Soil is thin or absent, and the surface is strewn with cobbles and well-rounded boulders of moderate size, from which the finer material has been washed or blown away. This material does not differ in character and manner of formation from the flood-plain gravel in front of the present glaciers. It is rock waste that was transported and deposited by the older glacial streams: partly material that was contributed directly by the melting ice and partly morainal material that was reworked and redeposited. Terminal moraines are exceptional in front of the present glaciers, and even when such moraines are formed they continue to exist for only a relatively short time, for they are soon destroyed by the shifting streams of water coming from the ice.

The depth of the outwash gravel deposits near the Delta River has not been dètermined but evidently is greater than the depth of the, valley that the river has cut in them, for the bedrock is not 
exposed. This is at least 200 feet in the terrace between 'Beales Cache and Jarvis Creek Bridge, over which the highway runs. Little is known about the character of the deposits except what may be seen on the surface, for no section was examined. Probably they are made up of beds and lenses of unsorted and partly sorted stream wash, such as is seen on some of the smaller streams. Also the cobbles and boulders strewn over the surface would indicate that much of the material is worn and well rounded. Possibly the deeper parts of the deposits may include older stream or lake gravel, such as the Nenana gravel.

Without doubt the waters of all the streams of glacial ice that crossed the highland area between the Delta and Johnson Rivers have contributed similar gravel deposits to the Tanana lowland area. These stream deposits and the morainal deposits were built up to a level higher than that at which present streams are working, and subsequently they were deeply trenched by streams that crossed them near the border of the lowland area.

The larger streams, such as the Delta, Gerstle, Little Gerstle, and Johnson Rivers, and Jarvis Creek, are loaded with waste material produced by the erosion of their valleys and have built up wide flood plains, over which their channels are continually shifting. In many places low gravel benches border the present flood plains and indicate former levels of these flood plains.

The material of the terraces and flood plains is largely the product of local erosion of the older rocks, but, as already stated, it contains a component of foreign glacial material and in places another component of the younger, partly consolidated deposits of the Tertiary coal-bearing formation and the Nenana gravel.

Attention has already been directed to the deposits of windblown sand, which cover most of the terraces and high banks near the larger streams and are widely distributed over the flood-plain areas.

Sand grains too heavy to be lifted and carried through the air for more than short distances may still be light enough for the wind to move over the surface of the gravel bars and collect in dunes or temporary beds and lenses. Almost any fixed object like a $\log$ or bush is sufficient to form a quiet eddy. where the sand settles and perhaps stays long enough for vegetation to start and hold it in place. Sand dunes 10 feet high were formed on the east side of Jarvis Creek above the mouth of Riley Creek.

The loess deposits or wind-blown sand of the terraces, together with the dunes of the flood plains, have their counterpart in thick deposits of coarse gray sand that overlie the gravel of the streams draining the north side of the granite area east of Granite Creek, 
and they appear to have been deposited by water rather than by wind. After leaving the granite area the streams lose their steep. gradients and are no longer able to move the heavy gravel, but they still carry a heavy load of sand, which is deposited where the grade diminishes further or the water seeps away through the gravel.

The sand is chiefly quartz and feldspar, which give the beds their light-gray color. In places it contains considerable magnetite. Much of it is overgrown with timber and other vegetation, but where the stream channels are cut into it, it shows a thickness of several feet. Such sand differs from wind-blown sand in being coarser and having more angular grains.

Most of the smaller streams of the district have steep gradients and occupy narrow valleys in which relatively small deposits of gravel have accumulated. Some streams like the Little Gerstle River show great quantities of granite boulders, and nearly all the streams in the district contain granite boulders in their lower courses, even where no granite crops out in the vicinity.

Some of the unconsolidated deposits near the streams are difficult to classify. On the west side of the narrow valley of July Creek, commonly known as Fourth of July Creek, and about 2 miles above its mouth is a section of yellow-weathering, unconsolidated material fully 200 feet thick. The lower two-thirds is a fairly homogeneous glacial stream wash with many boulders and a crude stratification. The lower half of the upper third is made up mostly of fairly fine gravel without boulders but with lenses and one persistent bed of glacial wash 20 feet thick. The remainder is glacial wash without stratification and is not so coarse as that forming the base of the section. On the top is wind-blown sand. These deposits except the sand were evidently laid down when the July Creek glacier was more active than now.

Other streams, as Jarvis and Macomber Creeks and the Gerstle and Little Gerstle Rivers, show analogous sections with an alternation of sorted and unsorted material. These deposits are the product of the more recent glaciation.

\section{GEOLOGIC HISTORY}

The events that occurred during the earlier geologic history of the Gerstle River district are obscure. This is due largely to the absence in the district of most of the sequence of deposits that make up the geologic column representing Paleozoic and Mesozoic time. No Mesozoic sedimentary rocks are present, nor are any rocks that can be. definitely assigned to the Paleozoic. Even the Cenozoic is sparingly represented. The oldest sedimentary rocks of the district were mostly 
sandstone and shale but are now so greatly altered that their original character is lost, and any fossil remains that they may have contained are completely destroyed so far as is known at present. Tentatively they have been correlated with the Birch Creek schist, which, as explained by Mertie, ${ }^{9}$ is the designation now used in describing the Yukon-Tanana region to include "all the older pre-Cambrian rocks that were originally of sedimentary origin." Future work may show that the metamorphic sedimentary rocks of the Gerstle River district are partly or wholly of Paleozoic age but no evidence in support of this possibility is at hand. The ancient sedimentary beds may have included lava flows or tuff beds, but if so, these rocks were not recognized. However, the sediments were intruded by igneous granitic rocks at different times and took part in mountain-building processes by which they were altered to schist and gneiss, as we see them now. These changes probably are the results of repeated application of the forces that produced them.

Not until relatively late geologic time did events take place that left; clearly understandable records of their occurrence. Some time in the. late Mesozoic the land was raised above the sea, and the formation of the present Alaska Range began. This mountain-building movement seems to have been intermittent in character and was made up of periods of elevation of the land separated by periods of quiescence. During periods of uplift erosion was accelerated. During quiet periods the processes of erosion proceeded at a gradually diminishing rate; yet at times reduction of the land was far advanced.

As a result of one such period of erosion the nonmarine Tertiary coal-bearing beds were formed. All the evidence, not only from the Gerstle River district but from elsewhere in central Alaska, tends to show that in early Tertiary time the land had long been above sea level and had taken on the characteristic features of mature topography. It was not a monotonous lowland, reduced practically to sea level, but possessed considerable relief. Its hills and mountains, however, were old and smooth-featured rather than rugged like the present Alaska Range. Lowland areas existed, as is evident from the character of the deposits that were formed and the vegetation that grew.

The Tertiary deposits are fresh-water deposits and accumulated on a land surface where streams of low gradient and quiet waters predominated. They are made up of shale, sand, and fine conglomerate, and never since their formation have they been depressed below sea level. The fine, well-sorted and well-stratified gravel, sand, and shale are not the product of rapidly flowing and actively eroding streams.

'Mertie, J. B., Jr., The Yukon-Tanana region, Alaska: U. S. Geol. Survey Bull. 872, p. $48,1937$. 
They were laid down in the quieter waters. The coal beds interstratified with the sand and fine gravel are fossil remains of beds of peat and other vegetation that grew on the surface just as similar vegetation grows today.

As has been stated by Capps, ${ }^{10}$ the long-continued, orderly formation of the coal-bearing beds appears at last to have been interrupted by a renewal of the uplift in the Alaska Range and a consequent rejuvenation of streams flowing from it. This in turn led to the rapid production of coarse gravel and sand. Thus the coarser deposits of the Nenana gravel were built up on the finer underlying beds of the coal-bearing group.

Deposition of the Nenana gravel seems to have immediately preceded the next notable event of the geologic history of the Gerstle River district, that is, the gradual onset of a period glaciation. Although the history of glaciation in most of Alaska is not fully understood and evidence has not been obtained to show that the alternating stages of advance and retreat of the ice front that took place in southern Canada and the northern United States during Pleistocene time had their counterpart in Alaska, it nevertheless is fairly well established that at least two stages of advance and retreat are indicated by glacial deposits along the north front of the Alaska Range and the east front of the Wrangell Mountains. Perhaps the most convincing evidence is found in certain deposits on the White River, where Capps ${ }^{11}$ examined beds of gravel, soft shale, and a little sand, "interrupted by sheets and lenses of glacial till in different stages of induration and by lava flows." These beds were locally tilted and deformed and were overridden by later glaciers. They were evidently much older than the more widespread glacial deposits of the region. No similar evidences of early glaciation were seen in the Gerstle River district, although the presence of morainal deposits containing deeply weathered granite boulders in contrast with morainal deposits in which the boulders are unweathered may have a bearing on this question. The weakness of the evidence from weathered and unweathered granite boulders lies in the presence of weathered boulders in the Tertiary gravel deposits, particularly the Nenana gravel. The weathered boulders in some of the glacial moraines may have been derived from this source so that it would be necessary to prove the source of the boulders in order to distinguish older weathered glacial deposits from more recent unweathered deposits.

The more recent glaciation must necessarily have destroyed much of the evidence of older glaciation in those areas where both took

\footnotetext{
${ }^{10}$ Capps, S. R., Geology of the Alaska Railroad region: U. S. Geol. Survey Bull. 907, p. $125,1940$.

"Capps, S. R., The Chisana-White River district, Alaska: U. S. Geol. Survey Bull. 630, pp. 63-67, 1916.
} 
place, particularly in an area of Alpine glaciation such as the one treated in this report. Only where the earlier glaciers extended beyond or above the limits of the more recent ice cover would the evidences of the earlier stage be likely to be preserved. So far as is known, most of the morainal deposits that have been described belong to the more recent stage of glaciation, which probably.corresponds with the Wisconsin stage of the northern United States.

As the accumulation of snow and ice in the high mountains gradually went on, icefields covered more and more of the intervening ridges, and streams of ice were extended down the valleys till finally the maximum advance was attained. This advanced position may have been maintained a long time, but eventually a reversal of the whole process began. The general advance and retreat of the ice were probably not continuous but were broken by minor fluctuations of advance and retreat, all of which required a long period of time for its accomplishment. During the general advance the valleys were widened and straightened and were swept clean of any unconsolidated deposits that may have been present. During the retreat the burden of rock debris carried by the ice was released and left to lie as it fell or to be sorted and redistributed by the streams. The same processes are in operation at present but because of the reduction in the extent and volume of the ice are less effective in bringing about changes in the topography than formerly.

A very recent event in the history of glaciation of the district is of such interest to the public in general and to students of glaciation in particular that it merits more than passing notice. This event is the spectacular advance of the Black Rapids Glacier, which took place in the winter of 1936-37 and is described in another section of this report under the heading, "Black Rapids Glacier."

\section{MINERAI RESOURCES}

\section{GOLD}

Just when prospecting began in the Delta River district is not known to the writer. Some of the stampeders to the Copper River Valley visited the upper Delta River in 1899 or 1900 . Active prospecting in the country on the north side of the Alaska Range, east of the Delta River, began about the time of the discovery of placer gold in the Fairbanks district and was carried on by a few men, most of whom made Fairbanks their headquarters and base of supplies, although others came into the district from the Copper River Valley. These men were in search of placer gold and gave their attention chiefly to the creek gravels, yet did not wholly neglect the possibility of finding lode deposits. The remains of their cabins, their old sluice boxes, and the pits they dug, may still be seen, but their efforts to find 
deposits that could be worked with profit met with little success and most of them left for more promising diggings. At present no mining and little prospecting is done in the district.

In certain respects the geologic conditions seem favorable for the occurrence of gold and other valuable minerals. The old schists and gneisses are cut by numerous granitic intrusive bodies of sizes ranging from thin dikes and sills to large irregularly shaped masses, and all underwent profound erosion during which many hundreds or thousands of feet of rock was removed and the heavy minerals were subjected to concentration.

Glaciation, however, swept from the valleys most of the unconsolidated deposits produced by erosion and probably with them the heavy minerals, such as gold, that may have been concentrated in the gravels. Furthermore, the present stream gravels in most places are so filled with granite boulders that placer mining would be both difficult and expensive.

Most of the prospecting for placer gold has been done in the area that includes Ober, Jarvis, and Macomber Creeks. Judging by the evidence of cabins, pits, and abandoned equipment, Ober Creek received most attention. At the forks of upper Ober Creek, 4 miles northeast of Donnelly Station, several holes were sunk in gravel that is reported to have yielded fair prospects. The country rock is schist. The ground is shallow and frozen, as is indicated by an abandoned boiler that was used for thawing. This part of Ober Creek is near timber line and originally had a scanty growth of spruce, most of which was cut for fuel and cabin logs. Probably much of the wood used for firing the boiler was hauled a considerable distance.

Nearby, across the narrow valley to the southeast, prospecting has been carried on more recently. A small stream comes down from the ridge on the east, cutting deeply into the light-gray yellow-weathering schist but building up its channel in the wider valley of the main creek. The rocks of the gulch are leached, faulted, and otherwise disturbed, so that they are conspicuous on the hillside. An automatic dam for sluicing and old pits at the mouth of the gulch show that some work was done here, but the results were not learned. A miner's notice showed that the ground had been restaked recently.

Little Gold Creek, which is tributary to Jarvis Creek, flows along the east border of the Tertiary coal-bearing formation. It would seem to be favorably situated for receiving and preserving any placer gold that may have been deposited with or reconcentrated from the Tertiary gravel and is reported to yield a little gold but not in paying quantity.

Macomber Creek, in its middle course, and the streams that come into it on both sides have entrenched their channels in a deep deposit 
of unconsolidated material that is partly Nenana gravel and partly glacial wash. Although a little gold is reported to be present in some of the gravel, no deposits of commercial value were found. This statement applies also to Pegmatite Creek, a tributary of the Little Gerstle River.

The search for lode deposits has met with no better success than the search for placer gold. In the absence of opportunity to talk with men who prospected the district little information concerning the work they did was obtained. Some evidence of their operations however, remains on the ground. In the early days the district was remote from settlements, but the physical conditions for prospecting were generally favorable, as exposures of the country rock are excellent in comparison with other places, where vegetation is more abundant and the overburden of unconsolidated material is greater. A striking feature of the geology is the abundance of white vein quartz. V.einlets and small lenses of quartz following the lines of foliation make up a large proportion of the schistose rocks. Larger veins, mostly of a different generation, follow the joint and fault planes that cut the schist. Some of the veins are mineralized. The writer found galena in stringers of quartz on a ridge northeast of the old cabin on upper Macomber Creek, and the gravel of some streams carries colors of gold, as has already been pointed out.

Prospecting for lode deposits was carried on at several widely separated localities in the district, including the valley of the stream that comes into the Johnson River from the east, opposite the south end of the valley between the Little Gerstle and Johnson Rivers, and Bradford Creek, which is a western tributary of the Gerstle River.

The best-known lode prospect of the district is a strong vein of ironstained quartz on Gunnysack Creek south of the Rapids Roadhouse on the Richardson Highway. This vein has been known for many years and was described by Capps. ${ }^{12}$ The vein crosses the creek about a quarter of a mile from the highway and cuts contorted quartzitic mica schist which forms the canyon walls on both sides of the stream. It is irregular in form although persistent, stands nearly vertical, and has a thickness of more than 20 feet in places. It consists of milky quartz stained with iron oxide resulting from the weathering of pyrite. Very high assays in gold were reported when the vein was first examined, and a short tunnel was driven to test further the value of the deposit, but the results were disappointing and the work was discontinued.

12 Capps, S. R., The Bonnifield region, Alaska : U. S. Geol. Survey Bull. 501, p. 54, 1012. 
COAL

The Tertiary coal deposits between the Delta River and Jarvis Creek appear to have aroused very little interest, although a considerable quantity of lignitic coal is available for use if any local demand should arise. A demand for coal, however, is unlikely while wood is as plentiful and handy as at present and while the only users are the roadhouse proprietors and trappers.

The coal beds are easily accessible from the Jarvis Creek side of the ridge but a climb of 1,200 to 1,500 feet in a distance of 4 miles would be required to reach them from the Richardson Highway 5 miles north of the Rapids Roadhouse. This climb would not be prohibitive if the coal were in demand.

The occurrence of the coal and its associated beds of sand, conglomerate, and sandy shale has already been described (pp. 127-131). The best exposures of coal are on the west side of Little Gold Creek near its head and on a little unnamed creek that flows almost parallel to Little Gold Creek on the west. Either of these localities is easily accessible from Jarvis Creek, but the one on the smaller creek is somewhat closer.

Near the base of the section on the smaller creek two beds of coal 5 to 8 feet thick, separated by about the same thickness of soft gray shale, crop out close to the channel. On the bare hillside above these two beds are many other thin beds of coal extending nearly to the top of the ridge on the west. The next largest and best appearing bed is in the middle of the section, nearly 300 feet above the two beds first mentioned. This bed is somewhat thinner, but the coal is clean and bright. All the beds lie practically horizontal.

In the saddle between the head of Little Gold Creek and the small tributary to Delta River two beds of coal crop out, one about 100 feet above the saddle and the other on the point of the ridge above, on the north. The lower bed is 10 feet thick, and the upper one slightly less. These beds are not exposed continuously along the west side of the valley of Little Gold Creek, being hidden under the loose rock fragments and vegetation, but undoubtedly these and other beds are present and could be found by removing the overburden on the hill slope. The small hill west of Little Gold Creek from which the section (p. 129) was derived contains a bed of coal 8 feet thick that may well correspond to the lower bed at the head of the creek. These beds are all horizontal and could easily be worked. Although the coal is not.of high grade it would be suitable for local use. 


\title{
BLACK RAPIDS GLACIER, ALASKA
}

\author{
By Fred H. Mofrit
}

\section{ABSTRACT}

The Black Rapids Glacier is one of the many glaciers of the Alaska Range. It belongs to the Delta River drainage and occupies a basinlike valley with an area of approximately 150 square miles west of the Rapids Roadhouse on the Richardson Highway. In the winter of 1936-37 the active front of this glacier made a sensational advance of more than 4 miles, an advance which clearly is a recurring event, as the evidence of several former advances is seen in old terminal moraines outside the present front. These advances take place after intervals of many years, during which snow and ice accumulate in the upper valley at a rate greater than that at which they are dissipated, till at last they overcome resistance to pressure and begin a brief, rapid movement. The pressure required to initiate the movement is greater than that required to maintain it after it has been started, and the advance of the glacier continues under diminishing force till it finally ceases and a new cycle begins.

\section{INTRODUCTION}

Early in 1937, newspapers published accounts of the unusual behavior of a practically unknown Alaskan glacier, which after years of quiet had suddenly begun to advance at an extraordinary rate. They referred to it as the Black Rapids Glacier and thus familiarized many persons with the name of a feature of the Alaska Range that hitherto had been of particular interest only to local residents and a few trained observers.

The movement of the glacier as described by the newspapers was so remarkable that most of those who read the accounts and had some knowledge of the nature and habits of glaciers were inclined to accept. the accounts with a good deal of reservation. The Geological Survey received many requests for pictures, maps, and information about this natural wonder, but although the front of the glacier had been mapped, its unusual character had been noted, and a few photographs had been filed, the Survey unfortunately had comparatively little information available for distribution. In September 1937 the writer, in conpany with T. W. Ranta, topographer, had an opportunity to spend several days at the Rapids Roadhouse and learn at first hand something about the glacier. The roadhouse is at mile 233 on the Richardson Highway, which connects Valdez on Prince William Sound with 
Fairbanks in the Tanana Valley. It is directly across the Delta River Valley from the glacier and only 1 mile distant, so that it not only is a favorable place for observation but would have been a dangerous place if the unusual movement of the ice had continued for only a short time longer.

\section{PHYSICAL FEATURES OF THE AREA}

In one sense the name "Black Rapids Glacier" is not appropriate, for Black Rapids is a feature of the Delta River and not of the glacier or of any part of its valley. In another sense the name is appropriate, for the rapids owe their existence, partly at least, to the great quantity of debris contributed by the glacier and by the stream flowing from its valley to the gravel deposits of the Delta River. This debris, by raising the flood plain of the river at this place and by giving the stream a gradient higher than average for a short distance to the north, produces the rapids.

The Delta River rises in the Tangle Lakes of the northern part of the Copper River Basin and flows northward through a deep canyonlike valley directly across the Alaska Range to the Tanana River. The upper river is a beautiful, clear stream of water, with gravelly bottom and wooded banks, but too deep for fording-with horses in most places. Before it reaches the entrance to the canyon through the Alaska Range it receives the water of two glacial streams, one on the west and one on the east. Some miles farther downstream, to the north, it receives water from the Canwell and Castner Glaciers on the east, and then, just as it passes the axis of the Alaska Range and is about to enter the area of the lower hills that border the range on the north, it is joined by waters that flow from the Black Rapids Glacier on the west. All these glaciers are active and discharge a large volume of black, dirty water, which destroys the beauty of the clear stream flowing from the Tangle Lakes and the small tributaries of the upper Delta River.

The valley or basin in which the ice of Black Rapids Glacier accumulates and from which the glacier flows lies in the heart of the Alaska Range and is surrounded by snow-covered mountains that rise to 13,000 feet on the north side of the basin and to 9,000 feet on the south side. The maximum relief of the mountains adjacent to the basin is thus over 10,000 feet, for the altitude of the bench mark in front of the Rapids Roadhouse is 2,129 feet. Much of the rim of mountains about the basin is above the line of perpetual snow. Every minor valley within the basin is occupied by an ice stream. 'The many tributaries from the minor valleys unite to form the main glacier, which finds its only outlet in the straight, narrow, canyonlike depression leading to the Delta Valley. (See pl. 10, A.) 
The valley of the Black Rapids Glacier is not easily accessible because of the necessity of crossing the Delta River in an unusually difficult place. If it were not for the fact that the mountains about the basin are good hunting country and that trappers have run their trap lines into the valley in winter when the streams are frozen, it is doubtful whether it would have been visited at all.

\section{EXPLORATION AND MAPPING IN THE AREA}

Apparently, the first white men to see the Black Rapids Glacier or, at least, to note it were members of the military expedition that Capt. E. F. Glenn led in 1898 from Cook Inlet, up the Matanuska Valley, across the Copper River Basin, and down the Delta River Valley to the mouth of Jarvis Creek, within 7 miles of the Tanana River. W. C. Mendenhall, now Director of the Geological Survey, was a member of this expedition, and "Col." H. E. Revell, now deceased, who later owned the Rapids' Roadhouse, was also a member. Mendenhall, ${ }^{13}$ in his account of the expedition, reported that the glacier that comes into the Delta Valley from the west, 12 miles below the Castner Glacier, showed a fresh moraine and seemed to be subject to more rapid fluctuations than the glaciers above.

In 1910, D. C. Witherspoon and C. E. Giffin mapped topographically the south side of the Alaska Range from the Delta River westward to the head of the Susitna River. At the same time, J. W. Bagley mapped the north side of the range from the Nenana River eastward to the Delta River. As part of his project Bagley mapped the front and lower end of the Black Rapids Glacier, but both he and Giffin stopped their survey at the high crestline that surrounds the valley of the glacier, so that the area within-approximately 150 square miles-has never been surveyed and the body of ice shown on the published map as occupying the upper part of the valley is largely diagrammatic. Bagley used a panoramic camera in his topographic surveying and took pictures of the lower end of the glacier. S. R. Capps, who accompanied Bagley's party as geologist, also took pictures of the lower valley. These pictures are not fully satisfactory, however, for they were taken in unfavorable weather at the end of a long field season when the party was making all haste to reach Valdez before snow had closed Thompson Pass. Although Bagley's field work was done in 1910, his map was not published until 1912 and bears that date. This fact has not been understood by some who have written about the glacier.

\footnotetext{
13 Mendenhall, W. C., A reconnaissance from Resurrection Bay to the Tanana River, Alaska, in 1898: U. S. Geol. Survey 20th Ann. Rept., pt. 7, p. 328, 1900.
} 
The Geological Survey did no further topographic or geologic mapping involving the Black Rapids Glacier from 1910 until Ranta resurveyed the front of the glacier and its lower valley in 1937. However, the recent advance of the ice aroused much general interest and led to studies by several observers outside the Survey, particularly J. H. Hance ${ }^{14}$ and O. W. Geist of the University of Alaska. Two representatives of Bradford Washburn of the Harvard Institute of Geographical Exploration camped near the glacier and made observations on it in July and August 1937. Members of the Alaska Road Commission, fearful that the auvance of the ice might interfere with the operation of the Richardson Highway, also watched the glacier in the earlier part of the year.

Ranta's topographic survey, which covered the vicinity of the Rapids Roadhouse, was made primarily to fill in a gap between Bagley's map and a map of an area surveyed by Gerald FitzGerald in 1936. Though the area to be covered by the new survey was east of the Delta River, it was most conveniently situated to furnish an opportunity for resurveying the front of the Black Rapids Glacier.

\section{CHANGES OBSERVED IN THE GLACIER}

The glacier as Bagley mapped it in 1910 and as Ranta mapped it in 1937 is shown in figures 5 and 6. The front of the ice as it appeared in September 1937 is shown in plate 11. It is important to notice the basinlike form of the upper valley and the abrupt change in direction of flow as the ice stream enters the narrow outlet that leads to the Delta Valley, for this doubtless had a great influence on the change in the glacier that took place in the winter of 1936-37.

Bagley's original map shows an embayment of the ice on the south side of the glacier that extended fully $11 / 2$ miles back of the present front. The lobe on the north side was well beyond the present front and is now represented by debris-covered hillocks of ice that have not been overtaken in the recent advance.

It is important also to notice the form and position of the old terminal-moraines: that Ranta outlimed on the map. (See fig: 6 and pl. 10, $B$.) Two such moraines are readily distinguishable. The outer moraine, which is necessarily the older, was more than three-fourths of a mile beyond the face of the glacier as it existed in September 1937. This moraine, though not continuous, is well-defined and is marked by heaps of glacial debris. When it was formed the end of the glacier was decidedly bulbous, and the parts of the moraine at the south border,

\footnotetext{
${ }^{24}$ Hance, J. H., The recent advance of Black Rapids Glacier : Jour. Geology, pp. 775-783, October-November 1937.
} 


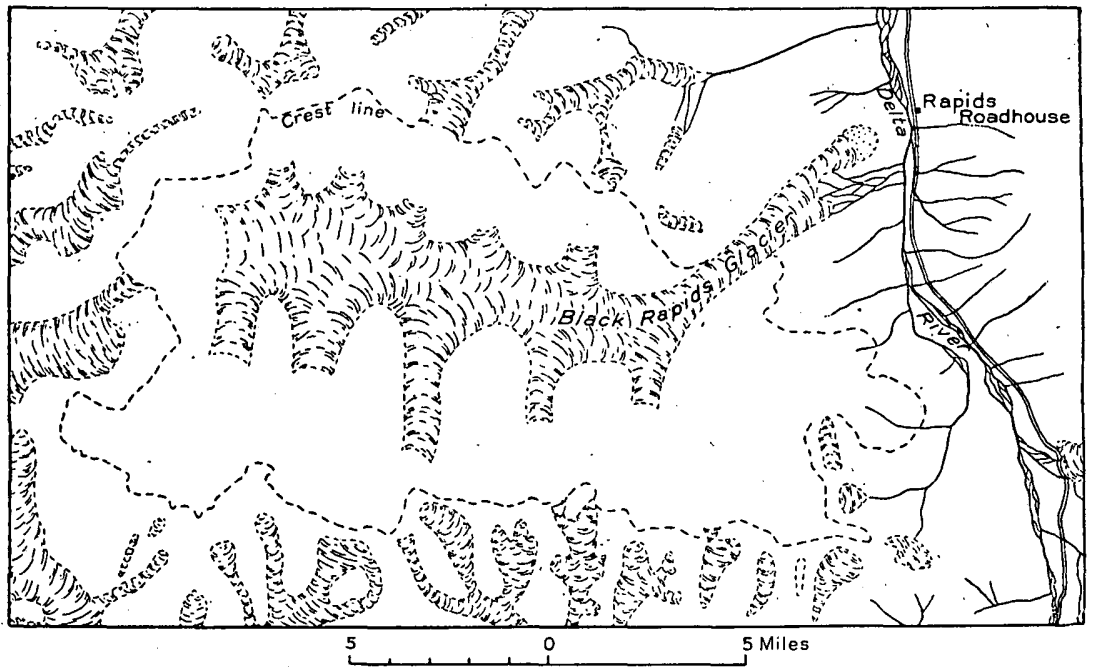

Figdre 5.-Map of drainage basin of Black Rapids Glacier as surveyed by J. W. Bagley in 1910. The outline of the glacier front is shown with the accuracy required by the scale of the map, but the form of the glacier in its upper part is approximate.

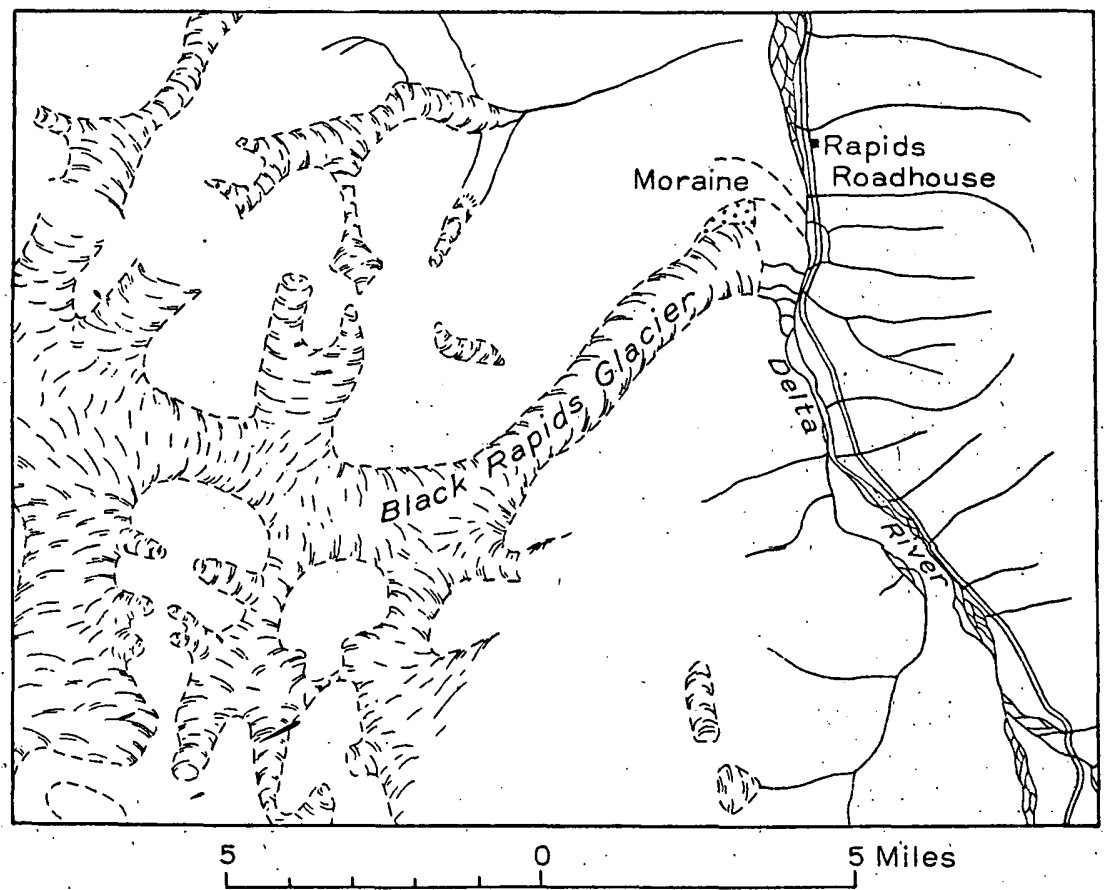

Figure 6.-Lower part of Black Rapids Glacier as surveyed by $T$. W. Ranta in 1937. Two old concentric terminal moraines are shown, and also an old moraine at the north end of the glacier, which, like the terminal moraines, was not reached by the ice in its recent advance. 


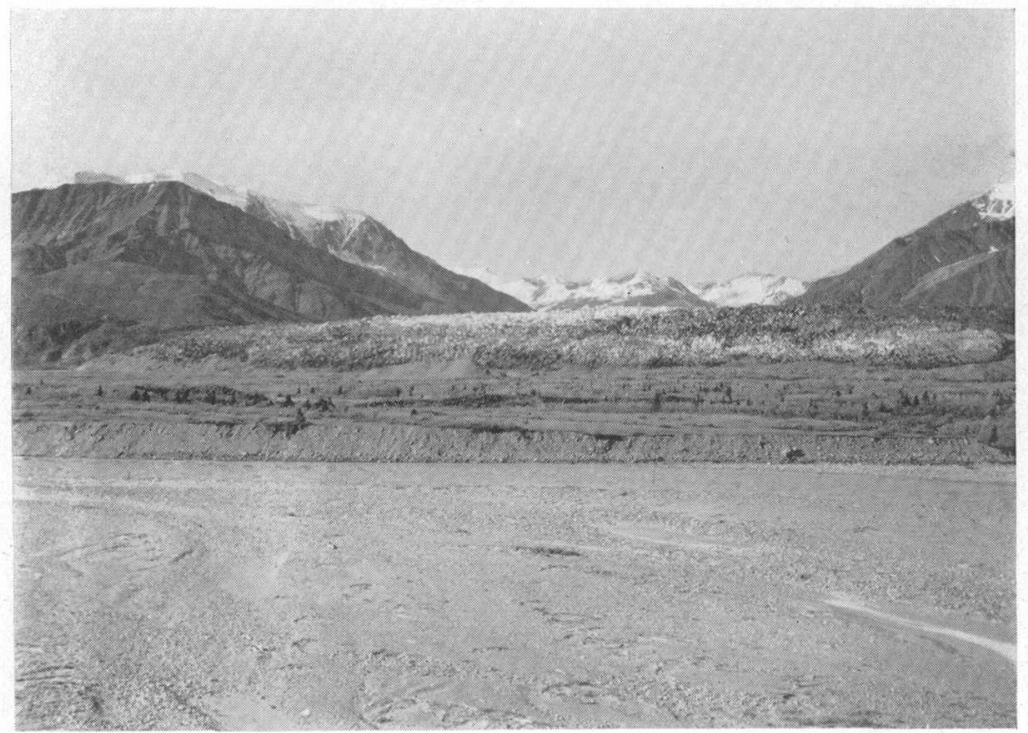

A. BLACK RAPIDS GLACIER FROM BROW OF GRAVEL TERRACE ABOVE RICHARDSON HIGHWAY, ABOUT 100 YARDS SOUTH OF RAPIDS ROADHOUSE.

View S. $50^{\circ}$ W., September 6, 1937.

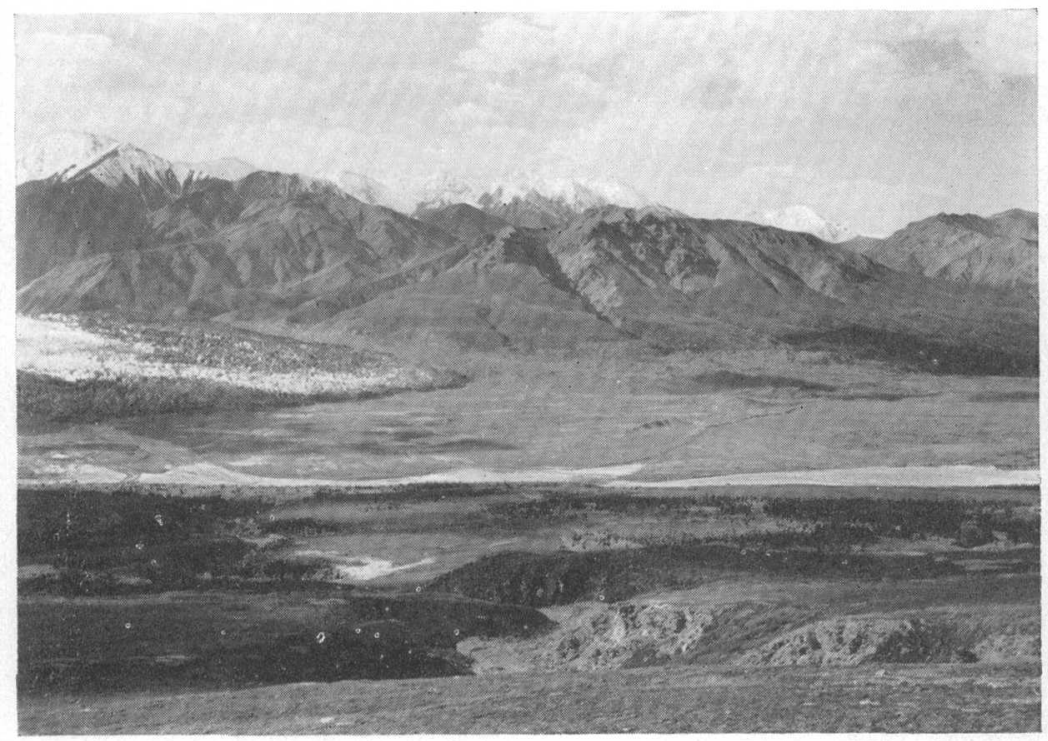

$B$, END OF BLACK RAPIDS GLACIER.

View from point on south side of Clear Creek, 2 miles south of Rapids Roadhouse. Altitude about 3.400 feet. Shows old morainal heaps near the foot of the mountains and a low terminal moraine extending diagonally to the right from the river near the center of the picture. A similar concentric moraine lies farther to the right, outside the field of view. September 6. 1937. 


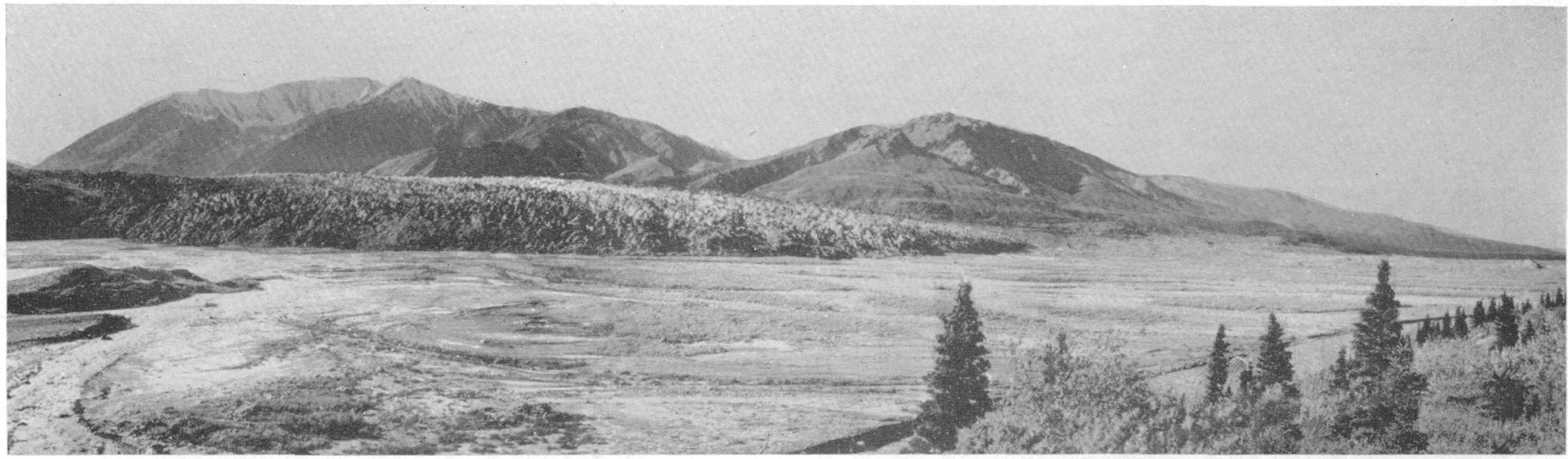

BLACK RAPIDS GLACIER FROM POINT ON GRAVEL TERRACE ABOVE RICHARDSON HIGHWAY, 2.1 MILES SOUTH OF RAPIDS ROADHOUSE. Delta River in foreground. Shows old moraines on right and left. September 6, 1937. 
controlled by the contour of the ice margin, trend east-west, or directly across the Delta River Valley. The inner moraine is about half a mile beyond the present front of the glacier. It is lower than the outer moraine but is continuous, or practically so, for it is broken through by only one small stream flowing from the glacier. From a distance it resembles a railroad embankment but is somewhat higher at the north end than at the south. Both these old moraines are truncated by the Delta River and are plainly visible at the edge of the low gravel terrace on the west side of the river channel. Although originally the moraines must have reached almost to the higher, timber-covered bench on the east, the river probably was able to maintain its channel between the ice front and the high bench, for it shows no evidence of having flowed over the bench. However, the possibility that it overflowed requires further investigation.

The weak point in all the accounts of the ice movement that took place in the winter of 1936-37 is the lack of accurate knowledge of the condition of the ice and the position of the active glacier front when the movement began. Bagley's map (1910) suggests that white ice, which would probably be moving ice, extended almost to the position of the present front. Capps' field notes, on the contrary, state definitely that no white ice appeared below the forks, or the place where the recent rapid movement was first noticed. It seems more likely then that even in 1910 a considerable part of the lower valley was occupied by relatively stagnant, debris-covered ice. This is the condition that has been described by some of the earlier observers.

From the statements of people who have hunted or trapped in the valley of the lower glacier; it would seem that in the 27 years since Bagley mapped the front of the ice the embayment on the south side was extended considerably farther upstream through melting and that part of the valley below the turn was occupied by a "dead glacier," or heaps of stagnant ice covered with morainal material. It is possible if not probable that the flood-plain gravels of the lower valley were underlain by ice, on which the advancing glacier may have coasted in its rapid movement, or which, more likely, helped to transmit the thrust from above and was plowed up as the glacier advanced.

The Rapids Roadhouse or hunting lodge is on the east side of the Delt River but is directly in line with the lower 5-mile stretch of the glacier and little more than a mile from the present front. It is now owned by Mrs. H. E. Revell, who related to the writer the story of the advance of the ice as she saw it. The valley of the Delta River is the route followed by airplane pilots in traveling between Fairbanks and points along the Copper River or the coast towns of Valdez and Cordova. Information about weather conditions in the Delta Pass is essential to these pilots and is furnished by Mrs. Revell. She is an observer for the Weather Bureau station at Fairbanks, is provided 
with the usual instruments-such as those for determining wind velocity and precipitation-and makes regular reports to the office in Fairbanks, as well as special reports when they are called for. The Delta Pass is closed to regular travel along the highway in winter, so that probably little would be known about the movement of the Black Rapids Glacier if the Revells had not occupied the roadhouse in winter.

The story of the advance of the glacier as told by Mrs. Revell is in substance as follows: During much of November 1936 the occupants of the roadhouse felt earth tremors and heard noises coming from the southwest, the direction of the glacier valley. Mrs. Revell supposed these to be caused by earthquakes, which are not uncommon in the Alaska Range, and reported them as earthquakes to the Weather $\mathrm{Bu}$ reau. On the $3 \mathrm{~d}$ of December, while sitting at the front window scanning the glacier valley with field glasses, she noticed that something extraordinary was taking place on the south side of the valley at the turn about 6 miles from the roadhouse, or at the "black points," as the mountain spurs on both sides of the valley at that place are called. Great blocks of ice were piled up in a jumbled mass on the south "point," where no ice had been before. She reported this to the office in Fairbanks without arousing apparent interest. A few days later, however, no question remained that something really unusual was taking place. The ice blocks now appeared at the black point on the north side of the valley, and a high wall of black and white ice had formed across the valley between the points. This wall was made up of masses of broken ice of all shapes and sizes-huge rectangular blocks, towers, spires, and jagged splinters-some black from the rock fragments they contained and some white like snow. As she watched the wall with the glasses from day to day she saw that the blocks were jostled about and that many were gradually tilted until they toppled over and fell in a cloud of snow and small fragments, followed by a roar and by a jar that rattled the windows of the roadhouse. She reported this to Fairbanks; and then for the first time the story was given to the papers.

Between December 3 and March 7 the wall of ice, as it appeared to Mrs. Revell, advanced from the black points nearly to its present position, or a distance of approximately 4 miles. The movement, insofar as it could be seen, was not a flow like the usual movement of glacial ice. The whole glacier appeared to be pushed forward, not as a solid unit but as a mass of jumbled blocks moving on a gently sloping surface. It seemed to slide rather than to roll. Bushes and rocks were not overridden but were caught up into the ice. The movement was not uniform across the front. A bulge or lobe formed at one point, then at another, and finally the part between the lobes was forced ahead till the line was regained. In this way the whole front margin of the 
ice was rapidly advanced down the narrow valley. Yet whether the whole mass of glacial ice was actually thrust forward so great a distance or whether the wall-like front was not in some degree the effect of an advancing wave of disturbance that took place in the stagnant, moraine-covered ice of the lower valley is not apparent from the known facts.

The present front of the glacier has caused less displacement of the old flood-plain gravels than one might expect. In places the dihedral angle formed by the ice wall and the gravel plain is clean-cut. In other places the roots of the vegetation hold the surface material together so that a roll or wrinkled body of turf is present at the line of joining; although it is nowhere especially conspicuous.

During the rapid movement of the glacier in the early part of 1937 the ice front was steep, but in September it was much less so, for the broken blocks, exposing a large surface to the sun and air, had melted rapidly. On the other hand, the sides of the glacier are remarkably steep and in many places perpendicular, and they show much less tendency to spread into side gulches than would be expected. Black, dirty ice generally makes up the sides of the lower glacier with white ice between, although black ice is there also. The surface of the glacier is exceedingly rough, so that walking on any part of the lower stretch is wholly out of the question. A study with glasses suggests that travel may be possible in places on the ice above the bend; yet not everywhere, for the main glacier a few miles above shows another stretch of tumbled blocks that have a much steeper grade than the surface immediately below, which possibly indicates a second wave of forward movement. This second stretch of broken glacier ice is in the eastern part of the gathering basin and, although it was viewed from a distance and therefore was not sufficiently examined to warrant a positive statement, it seems highly improbable that it is a cascade in the ice stream caused by uneven bedrock in the channel.

Ponds or small lakes that formed in places where drainage was blocked by the ice were reported by the airplane pilots who fly through the Delta Pass. At least one such lake was seen from the high mountains east of the Delta. Probably most of these lakes are only temporary and will be emptied as soon as the water is able to cut an outlet channel or force its way beneath the ice. A sudden flood of glacier water that came from the valley in July 1937 probably originated in this way. Such floods occur regularly with some Alaskan glaciers. Most of the floods are peculiar in that they are due not to the overflowing of a basin that has been filled but rather to the aocumulation of a head, which in some way results in an escape of the water through a channel beneath the ice. The flood comes suddenly and ends quickly, with the complete emptying of the reservoir. 
Any estimate of the average daily movement of the glacier during the 3 months of most rapid advance involves uncertainties arising from the apparent lack of precise information about the condition of the glacier when the advance began. If we accept as the best information obtainable the statement of Mrs. Revell that the ice wall which she first saw forming on the south side near the bend of the glacier on December 3 had advanced nearly to its present position by March 7, the average daily movement must have been at least 200 feet. It should be remembered that Mrs. Revell's first observations of the movement of the glacier were made at a distance of about 6 miles. Later, both Mrs. Revell and others visited the front of the ice at close hand and measured the movement by referring to objects on the ground.

Hance, ${ }^{15}$ in his excellent description, says that from his own observation from the Richardson Highway in 1936 and from the observations of others he would place the front of the ice 3 miles from the Delta River Valley when the advance began. He states, however, and shows by photographs taken from an airplane in February, that the old moraines or debris-covered ice mounts extended an unknown distance in front of it. Basing his estimate on his own observations, he calculates an average daily forward movement of 115 feet and says that local observers have measured a movement of 250 feet in one day.

R. B. Shepard, of the Alaska Road Commission, measured an advance of 400 feet in 7 days, an average of 57 feet a day. Geist, of the University of Alaska, is reported to have measured a movement of 17 to 18 feet a day in March. The most rapid advance was in December and January. By September 1937 it was evident that the movement was too small to attract special attention, and, according to the Valdez Miner of December 31, Mr. Revell reported that no movement had taken place in 2 months except unimportant local adjustments but that sounds as of crashing ice were heard from far up the valley.

\section{CAUSE OF THE ADVANCE OF THE ICE}

The cause for the unusual advance of Black Rapids Glacier is not easy to determine. Probably more than one factor was involved, but so little is known of the condition of the glacier previous to the winter of 1936-37 and so little has been learned since then that it is difficult to evaluate the factors. Basically, the reason for the movement of any glacial ice that is free to move is the accumulation of more snow than is melted in the milder seasons of the year. This snow is compacted and recrystalized and becomes glacial ice. When sufficient ice accumulates, the movement of the ice is brought about by

${ }^{16}$ Hance, J.·H., op. cit., p. 776. 
the force of gravity; for the glacier seeks a lower level, just as water does. Given a fairly uniform supply of snow it might be expected that, except for seasonal differences, the movement of the glacier would be nearly constant unless some unusual outside influences come into play; and that is what appears to be true of the movement of most of the active Alaskan glaciers.

An unusual movement of the glaciers of the Glacier Bay area, in southeastern Alaska, which took place in 1899, is attributed to the disturbing influence of a violent earthquake. Earthquakes occurred in the area of the Black Rapids Glacier in 1936 and 1937, as they have frequently occurred in the past, but they were not exceptionally violent and probably cannot be considered as anything more than a contributing cause of the advance of the glacier, if they had any influence at all.

Hance ${ }^{16}$ made a study of the records of precipitation for the Fairbanks district and reached the conclusion that the advance of Black Rapids Glacier in December 1936 and January 1937 was due to excessive precipitation during the years 1928-32, which was about 17 percent above the mean for those years. He believes that excesses and deficiencies of snowfall are a cause of oscillation of the ice front and that they require about 4 years' lapse of time to make themselves felt at the lower end of the glacier.

It seems reasonable, if not necessary, to suppose that variations of snowfall will have an effect on the movement of the glacier; yet it also seems necessary to look for some further cause of the extraordinary movement in this particular glacier, especially as none of the many other glaciers in the vicinity are reported to have had any corresponding movement. Hance himself recognizes that records of precipitation at Fairbanks may not fully correspond with local weather conditions of a basin in the Alaska Range 100 miles away.

It is suggested that the rather unusual combination of high mountains, a comparatively large gathering basin, and a constricted outlet provide conditions for a superaccumulation of ice. The free movement of the glacier being obstructed, snow and ice continue to pile up in the basin till a pressure greater than that required to maintain free flowage under more usual conditions is built up. Any one of several causes, such as excess snowfall, excess rainfall, earthquake shock, or possibly other more obscure causes, might serve as an immediate occasion for the sudden yielding to accumulated stresses that evidently. took place, although increasing pressure alone would eventually bring about the movement.

10 Hance, J. H., op. cit., pp. 780-781. 
Experiments on ice flowage that were conducted by 'Tarr and Von Engeln ${ }^{17}$ at Cornell University in the winter of 1911-12 to determine the nature of ice and its behavior under varying conditions of pressure and temperature appear to substantiate both qualitatively and quantitatively the principal conclusion that the writer had reached in regard to the movement of the Black Rapids Glacier. A description of the experiment would require too much space to permit its being given here; but one important fact brought out by the investigation was that the flow of ice in the form of unsupported cubes subjected to increasing pressure requires a greater force for its initiation than for its maintenance after the flow has once started. Although other factors, particularly temperature, enter into the problem of the flow of glacial ice, the factor just given seems to bear directly on the problem.

In applying the results derived from a study of the experiments to the behavior of glacier ice, Von Engeln ${ }^{18}$ made a statement that might well have been intended for the Black Rapids Glacier. Under the heading "Reservoir lag and wave of advance," he says:

Climatic variations, differences in the amount of precipitation for a series of years, determine the general advance or retreat of the glaciers of a given region, and such climatic variations are perhaps uniformly effective the world over. But individual glaciers may exhibit phenomena of advance and retreat in a sort of irregular pulsation apparently independent of the general climatic factor. Such pulsation has been ascribed to the effect of what may be termed reservoir lag. It is conceived that the reservoir basin of a glacier must be filled up to a certain level before the pressure attains a sufficiently high measure to initiate flow. Once this point is reached, however, the effects due to beginning flow are rapidly augmented and the accumulated reservoir material pours down the glacier tongue as a wave of advance. Such an advance is followed by a longer period of wastage and consequent shrinking of the ice tongue while the reservoir is once more filling.

There is a very close analogy between such behavior of glaciers and that of unsupported ice cubes that were caused to flow under compression. In these experiments a certain minimum pressure was necessary to induce flow, but once flow had begun it proceeded rapidly under diminishing pressures. In glaciers, similarly, pressure is gradually augmented by the increasing depth of accumulated snow, until the yield point is attained, when flow begins and continues at pressures much lower than those required to initiate the advance. During the period of accumulation the snow and ice mass of the reservoir is under practically uniform pressure and the cold snow is being gradually raised, by inflow of earth heat, to the pressure-temperature equilibrium. Once flow is started the pressures are of the nonuniform character with resultant increase and decrease of the thickness of interstitial solution and a consequent increasing fluidity of the mass. The starting of the flow is a function of both rising pres-

17 Tarr, R. S., and Von Engeln, O. D., Experimental studies of ice with reference to glacial structure and motion: Zeitschr. Gletcherkunde, 9te Band, 1914-15, pp. 81-144, Leipzig, 1915.

18 Idem., p. 137. 
sure and rising temperature; its continuance and acceleration, one of localization of maximum stresses with relief by thickening of the interstitial film, the reconsolidation of this excess liquid at positions of less pressure resulting in a redistribution of stresses.

The references to temperature and interstitial film of water in the second paragraph of this quotation relate to the internal conditions of the ice in the body of the glacier. They are additional factors on which the flow, of the ice is dependent for its beginning and continuation and were considered at length in the earlier part of Von Engeln's paper. As they are not peculiar to the Black Rapids Glacier, however, they need not be discussed here.

Applying the ideas just considered to an explanation of the advance that took place in the glaciers of the Yakutat Bay Region after the earthquake of 1899, Von Engeln ${ }^{19}$ says further:

Once started, the wave of advance moved very rapidly to the end of the glacier, apparently in the nature of a viscous underflow which greatly disrupted the rigid upper ice layers and apparently transmitted the effect of its thrust to the terminal portions of the glaciers before the actual wave reached such points.

Such waves of advance are accompanied by a swelling of the glacier tongue that would be extremely difficult of explanation by any hypothesis of rigid forward thrust of the ice.

Whether Von Engeln intended that the cycle of events implied in his description of the process of ice movement should be applied to a recurrence of accumulation, advance, and retreat involving a period of time as long as is suggested by conditions at the Black Rapids Glacier is not evident from his paper, yet there seems to be no good reason for limiting the application of the cycle to short periods of a few years. In this connection it would be interesting to investigate the Castner and Canwell Glaciers on the east side of the Delta River, for, although smaller than the Black Rapids Glacier, they exhibit some similar features, particularly an open gathering basin that drains through a narrow outlet.

Although the Black Rapids Glacier has shown an unusual advance only once since it was first seen by white men, this was not the first advance but rather the last of at least three advances, as there is clear evidence of the earlier two in the old terminal moraines. It is probably impossible to tell whether other more ancient advances took place, the evidence of which has been destroyed. It seems reasonable to conclude that the events of the winter of 1936-37 may be repeated some time in the future, although if we judge the future by the recent past we may assume that they are not likely to recur in the lifetime of this generation.

${ }^{10}$ Op. cit., p. 138. 



\section{INDEX}

Abstract
Alaskowledgments for aid.

Birch Creek schist, use of name--.---

Black Rapids Glacier, condition of, previous to November 1936

exploration and mapping in area of - 148-149

location of

movement of, in 1936-37 _ 146, 151-154 causes of _.......-_._- 154-157

name of

physical fentures of -_-_-_-_ 149-151, pls. 10, 11

Brown, R. W., fossils identifled by -.-- $\quad 130$

Coal, occurrence of-_.-- 118, 119, 127-130,

145 , pls. $6, B, 7, A$

al-bearing beds, origin of._._. 140,141

$\mathrm{x}^{\mathrm{k}}$ section of 129

Delta River, prospecting near_-_ -- 142

Delta River Valley, features of - 111, 147-148

Dikes, occurrence of

Donnelly Dome, features of -_- 110, pl.5, B

Drainage of the district__._._._._. 110-113

Field work_._. 109

Floods caused by glacial waters_._._. 153

Forage, availability of _._._._._- 113-114

Fossils in the district, Tertiary 130,134

Eourth of July Creek, deposits along-- 139

Game, kinds of

Geography of the district__._._-_- 109-118

Geologic history of the district._ $118-119$,

n: $: 4$.

nnlogy, ceneral features of

pl. 3 (in pocket)

arstle River, features of _._._... 111 gravel deposits. near....... pl. 8, $A, B$

Incial deposits, character and dis-
tribution of -
pls. $8, C, 9, B, 10, B, 11$

$\because$ Glaciation, extent of

history of

Glaciers, floods caused by _._._._. 153 movement of

See also Black Rapids Glacler.

Gold. occurrence of _._._._._. 143-144 prospecting for

Grass, kinds of

Gunnysack Creek, gold lode on
Ice flowage, experiments on_r Page

Igneous rocks, age, character, and distribution of -_-_-_- 119-126

Jarvis Creek Glacier, view across_-_- pl. 4 Johnson River, features of _..._._. 111-1.12 July Creek. See Fourth of July Creek.

Lakes, temporary, caused by glaciers_-_ 153 Lignitic coal beds, occurrence of, in Tertiary rocks_- $128,130,145$

Little Gerstle River, features of -... 111

Little Gold Creek, coal near_ 129, 145, pl. 6, B erosional remnants near._._._. pl. 6, $A$ fossils from__._. 130 gold on section of beds on

Location of the district_._._._. 108 Loess deposits, occurrence of._-__- 113, 138

Macomber Creek, gold on__._._._. 144

Nenana gravel on Mesozoic time, events of _..._... 140 Morainal deposits, character and dis.

tribution of _._._- 135-137, 149-151, pls. 8, $C, 10, B, 11$ Mount Kimball, height of _-_._._. 109-110

Nenana gravel, age of character and distribution of -- 131-133, pls. $7, B, 8, A, B$ structure of 133 Ober Creek, prospecting on 143

Paleozoic or pre-Paleozoic rocks, age and correlation of_._. 122-123, 140

character and distribution of -- 119-121 thickness and structure of _-_ 121-122 Pegmatite Creek, gold on__._._._._. 144 Pre-Tertiary rocks, age of character and distribution of _- 123-120

Rapids Roadhouse, location of _-_ 146-14? Relief of the district__._._._._. 109-110, pls. 2 (in pocket), 4,5

Revell, Mrs. H. E., information furnished by _..._._._. 151-154

Robertson River, features of 112 Routes and trails__________-_ 114-11i

Sand deposits, general features of -- 138-139 Sand dunes, occurrence of _-_-_ 1.12-113, 138 Sheep Creek, view of _._._._._. pl. 9, B Sills, occurrence of Stocks, occurience of Stream deposits, general features of - 137-139 
Surveys in the district

Tertiary time, events of

Tanana River Valley, features of ----

Tertiary rocks, age and correlation

110 Timber, extent of

Topography of the district__._._- 109-113,

of -

character and distribution of --- 127

fossils fiom

thickness and structure of pls. $6,7,8, A, B$
Transporation in the district_-_--- 114-116

Vegetation of the district_-_-_-_-_ 113-114

Von Engeln, O. D., quoted_._._._ 156-157 